\title{
First selective direct mono-arylation of piperidines using ruthenium-catalyzed $\mathrm{C}-\mathrm{H}$ activation
}

\author{
Maria C. Schwarz • Navid Dastbaravardeh • \\ Karl Kirchner • Michael Schnürch • \\ Marko D. Mihovilovic
}

Received: 4 January 2013 / Accepted: 10 February 2013/Published online: 3 April 2013

(C) The Author(s) 2013. This article is published with open access at Springerlink.com

\begin{abstract}
A Ru-catalyzed mono-arylation in $\alpha$-position of saturated cyclic amines is reported employing a $\mathrm{C}-\mathrm{H}$ activation protocol. Substitution of the pyridine directing group with a bulky group, e.g., trifluoromethyl in the 3-position, proved to be crucial to avoid bis-arylation. This highly selective transformation can be performed with different amines and arylboronate esters. Additionally, the directing group can be cleaved, taking advantage of an unprecedented detrifluoromethylation reaction.
\end{abstract}

Keywords Catalysis - Heterocycles $\cdot \mathrm{C}-\mathrm{H}$ activation . Metal carbonyls · Arylation · Detrifluoromethylation

\section{Introduction}

Transition-metal-catalyzed C-H activation has become an important tool for organic chemists in recent years [1-8]. Activation of $\mathrm{sp}^{2} \mathrm{C}-\mathrm{H}$ groups is already well established [9-17], and though transition-metal-catalyzed $\mathrm{sp}^{3} \mathrm{C}-\mathrm{H}$ activation is more difficult, there are also various recently reported examples [18-31]. This approach offers an appealing method towards more efficient synthetic pathways with fewer steps, since pre-activation of carbons with functional groups can be avoided.

$\alpha$-Substituted saturated $\mathrm{N}$-heterocycles can be found in natural products such as alkaloids, as well as in drug compounds $[32,33]$. Hence, utilization of the $\mathrm{sp}^{3} \mathrm{C}-\mathrm{H}$ bond for $\mathrm{C}-\mathrm{C}$ bond-forming reactions in $\alpha$-position to the

M. C. Schwarz · N. Dastbaravardeh · K. Kirchner ·

M. Schnürch $(\bowtie) \cdot$ M. D. Mihovilovic

Institute of Applied Synthetic Chemistry, Vienna University

of Technology, Getreidemarkt 9/163-OC, 1060 Vienna, Austria

e-mail: michael.schnuerch@tuwien.ac.at nitrogen is of special interest, since it provides an efficient pathway towards a valuable building block that is tedious to obtain via other methods [34].

Due to the importance of $\alpha$-arylated cyclic amines, several groups have undertaken efforts to develop direct arylation methods towards these compounds. Sames and coworkers reported the first direct $\alpha$-arylation via $\mathrm{C}-\mathrm{H}$ activation of saturated cyclic amines, primarily pyrrolidines, using a ruthenium catalyst and arylboronate esters as coupling partner (Scheme 1, upper part) [35]. A cyclic imine was used as a directing group, and the presence of a ketone proved to be essential for this reaction. In 2010, the group of Maes published a ruthenium-catalyzed, pyridinedirected $\mathrm{C}-\mathrm{H}$ activation of piperidine derivatives in the presence of an alcohol, again involving arylboronate esters as coupling partners (Scheme 1, lower part) [36].

Both of these methods have one notable limitation; i.e., no selective mono-arylation could be achieved. In one case the second $\alpha$-position was blocked to avoid bis-arylation (Sames' protocol); in the other case a mixture of mono- and bis-arylated products was obtained (Maes' protocol). Bis-arylation not only decreases the yield of the mono-arylated compound but also leads to difficult separation due to similar properties of mono- and bis-arylated compounds. The best yield for selective mono-arylation reported to date was published by Maes with $49 \%$ [arylation of (pyridin-2-yl)piperidine with 3-(trifluoromethyl)phenyl boronic acid ester] [36]. Herein, we report on selective mono-arylation of saturated cyclic amines achieved using a specially designed directing group.

\section{Results and discussion}

Bis-arylation occurs due to a low energy barrier for rotation of the directing group around the $\mathrm{C}-\mathrm{N}$ bond as observed for 
Scheme 1

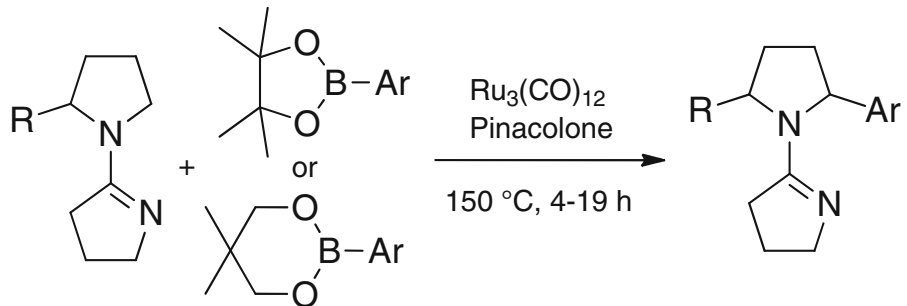

Maes:

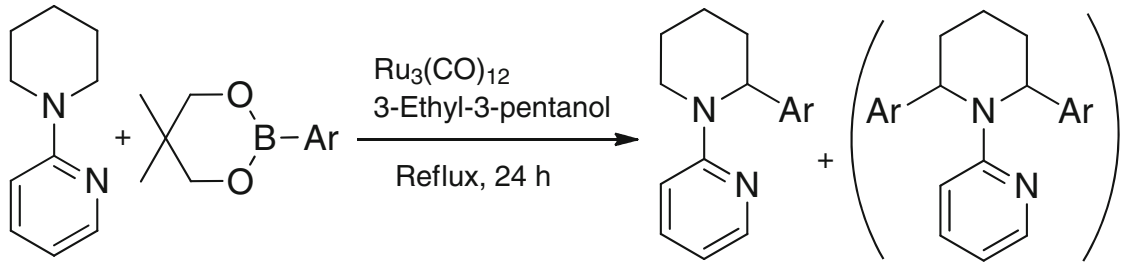

Scheme 2

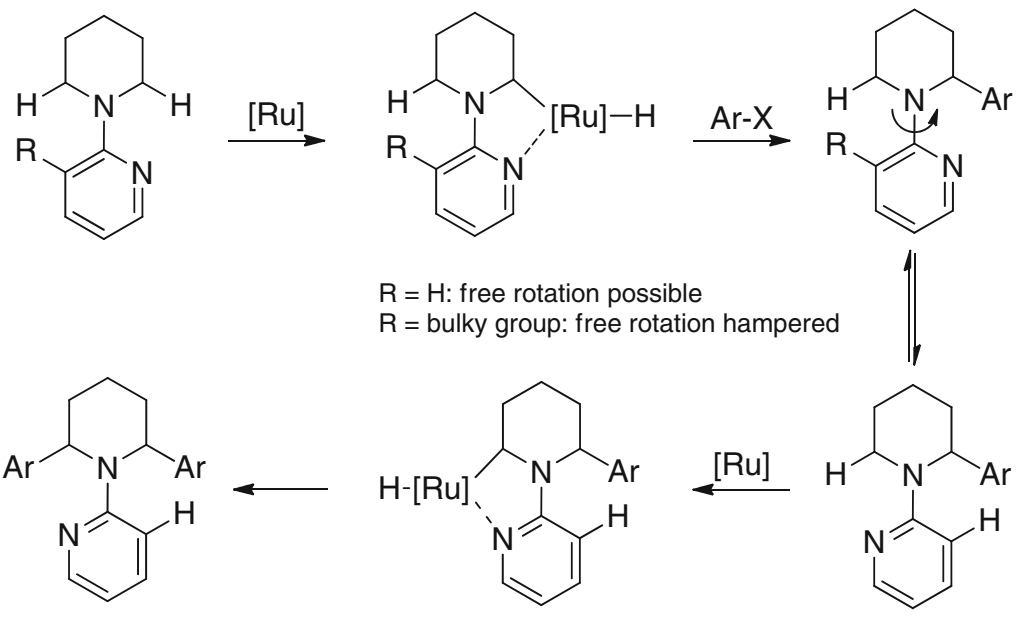

only possible if $\mathrm{R}$ is small enough, e.g. $\mathrm{H}$

pyridine or the cyclic imine. Free rotation therefore allows insertion of the catalyst into both $\mathrm{C}-\mathrm{H}$ bonds after complexation of the catalyst to the nitrogen of pyridine (Scheme 2). For this reason, it was envisioned to install a bulky group in 3-position of the pyridine directing group to hamper this free rotation, subsequently avoiding a second arylation step. The trifluoromethyl group was chosen for several reasons: (i) similar directing groups have already been successfully applied in direct arylation reactions [37-39]; (ii) it gave better results as compared with the simpler $\mathrm{CH}_{3}$ group (typically $\sim 10 \%$ better conversion); (iii) only mono-arylated product was obtained in the initial screening; and (iv) it is easy to install in good yields.
In most cases the directing group was installed by simple nucleophilic aromatic substitution (Table 1). Therefore, 2-chloro-3-(triflouromethyl)pyridine (1) was reacted with saturated amine 2, adding $\mathrm{K}_{2} \mathrm{CO}_{3}$ and using acetonitrile as a solvent. Except 3b (Table 1, entry 2) and 3k (Table 1, entry 11), all products could be obtained in excellent yields. The rather low yield of $\mathbf{3 b}$ is probably due to steric hindrance of the methyl group adjacent to the piperidine nitrogen. Though 3k showed conversion of $74 \%$, only $37 \%$ of pure product could be isolated, which can be attributed to significant volatility of the product leading to losses upon solvent evaporation.

Having a series of starting materials in hand, the direct arylation reaction was optimized. Initially, the $\mathrm{C}-\mathrm{H}$ 
Table 1 Synthesis of substrates for direct arylation
${ }^{a}$ Reaction conditions: 1

( 1 equiv.), saturated amine 2

(2 equiv.), $\mathrm{K}_{2} \mathrm{CO}_{3}$ (2 equiv.), acetonitrile

b 3 equiv. saturated amine

${ }^{c}$ Microwave heating

${ }^{d}$ Round-bottom flask, reflux conditions

e Closed vial, heating block

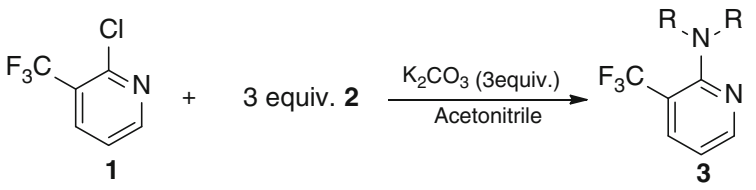

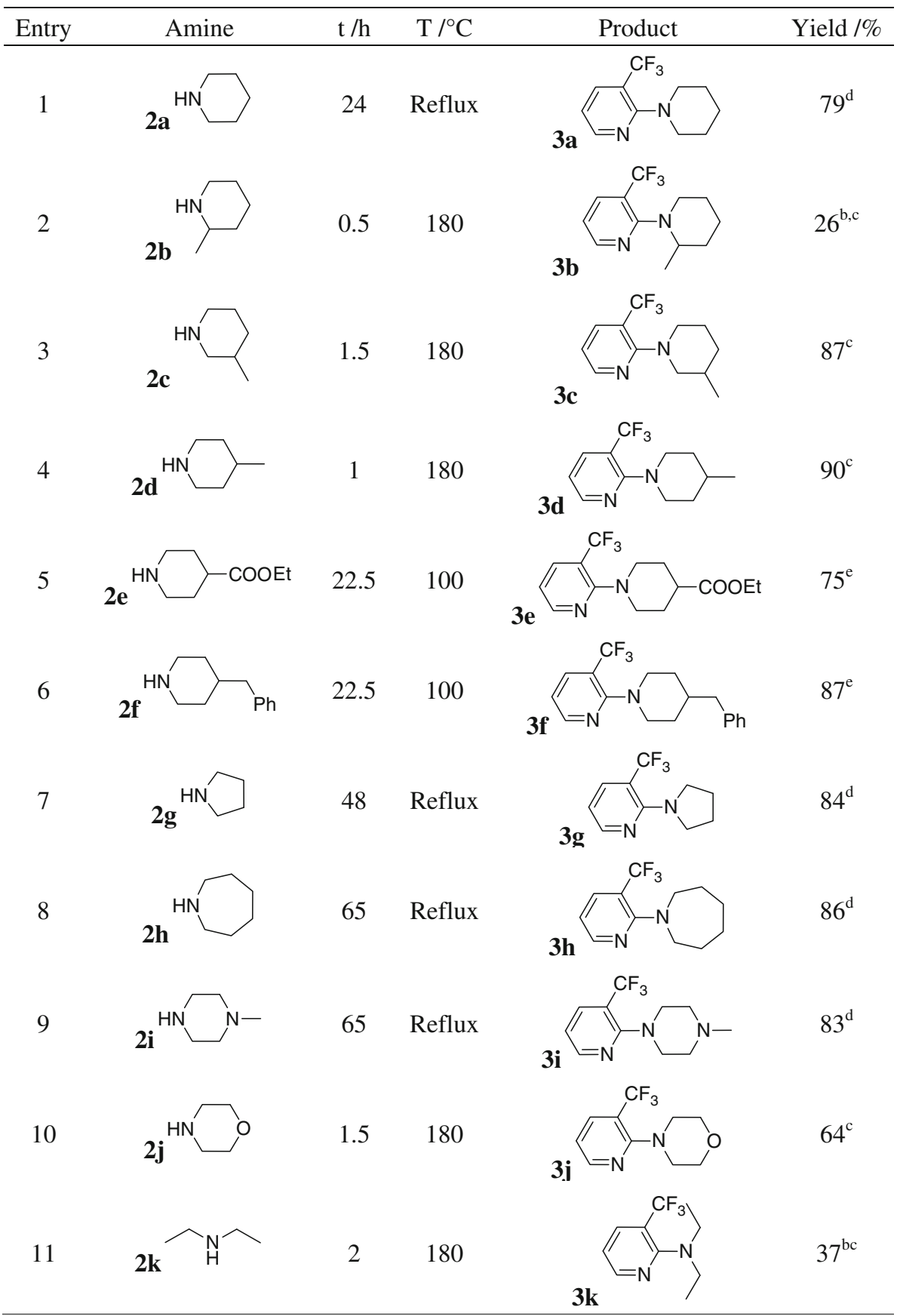

activation was performed with $\mathrm{Ru}_{3}(\mathrm{CO})_{12}$ as catalyst and 1,3-propanediol derived boronic esters as the aryl donor, similar to previous literature examples $[35,36]$ and being easily prepared from the corresponding boronic acids [40]. As we observed also deborylation besides the desired arylation reaction, an excess of 4 equiv. of arylboronate ester was used. Maes reported that addition of an alcohol (e.g., 2,2-dimethylpropane-1,3-diol) was beneficial in his piperidine arylation protocol, since the alcohol should scavenge a diol-borane species formed after transmetallation [36]. Hence, we also tried addition of 2,2-dimethylpropane-1,3diol. The reaction was performed in a reaction vial with a 
septum cap and an attached argon balloon to "release" hydrogen which should be formed according to the mechanism proposed by Maes. The reaction was carried out in $o$-xylene as solvent at $135{ }^{\circ} \mathrm{C}$ for $36 \mathrm{~h}$. With those conditions (Table 2, entry 1) conversion of $53 \%$ could be achieved. Changing the nature or amount of alcohol had no significant influence on the reaction outcome. In the Maes protocol, 1 equiv. of alcohol was used [36]. In our case it did not make any difference whether we used 0.5 or 1 equiv. of alcohol additive. Increasing the catalyst loading did not improve the yield either. Also, longer reaction times did not increase the yield (data not shown). It turned out that, after a significant amount of screened reaction conditions, the only modification that could increase the yield significantly was to add a metal salt as co-catalyst. Table 2 presents a selection of metal salts applied. Addition of $\mathrm{PdCl}_{2}$ (entries 2-4), $\mathrm{FeCl}_{2}$ (entries 5-7), $\mathrm{FeCl}_{3}$ (entries 8-10), $\mathrm{CuCl}_{2} \cdot 2 \mathrm{H}_{2} \mathrm{O}$ (entries 11-13), and $\mathrm{CuSO}_{4} \cdot 5 \mathrm{H}_{2} \mathrm{O}$ (entries 14-16) led to improved conversion, with $2 \mathrm{~mol} \% \mathrm{CuSO}_{4} \cdot 5 \mathrm{H}_{2} \mathrm{O}$ giving the best gas chromatography (GC) yield of $70 \%$. It can only be speculated that the metal salt may help to keep the catalyst in the required oxidation state, but evidence for this is lacking. To investigate the role of $\mathrm{CuSO}_{4} \cdot 5 \mathrm{H}_{2} \mathrm{O}$ and to exclude that $\mathrm{CuSO}_{4} \cdot 5 \mathrm{H}_{2} \mathrm{O}$ alone could serve as a catalyst in this transformation, the reaction was carried out in the absence of $\mathrm{Ru}_{3}(\mathrm{CO})_{12}$; as expected, no formation of the product could be observed.

A slight increase of the temperature to $140{ }^{\circ} \mathrm{C}$ still gave the same conversion, but the reaction time could be decreased to $24 \mathrm{~h}$. Further increasing the temperature was not beneficial and lower conversions were obtained, which most likely can be attributed to catalyst decomposition. Since the kind of alcohol had no influence on the yield, 0.5 equiv. of 1,3-propanediol was used instead of 2,2dimethylpropane-1,3-diol. This change was conducted as the 1,3-propanediol derived boronate was much easier to separate from the product in the workup process and the nature of the boronic ester had no significant influence on the substrate conversion. At this point it could be argued that the avoidance of bis-arylation is no advantage over existing protocols,

Table 2 Optimization of the reaction conditions ${ }^{\mathrm{a}}$

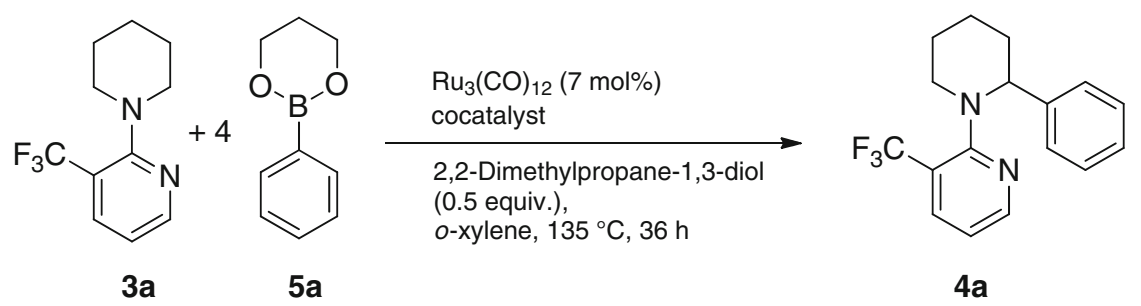

\begin{tabular}{lllll}
\hline Entry & Co-catalyst & Mol $\%$ & Conversion/\% ${ }^{\text {b }}$ & 39 \\
\hline 1 & - & - & 53 & 43 \\
2 & $\mathrm{PdCl}_{2}$ & 1 & 53 & 54 \\
3 & $\mathrm{PdCl}_{2}$ & 3 & 70 & 49 \\
4 & $\mathrm{PdCl}_{2}$ & 5 & 65 & 54 \\
5 & $\mathrm{FeCl}_{2}$ & 1 & 72 & 61 \\
6 & $\mathrm{FeCl}_{2}$ & 2 & 75 & 63 \\
7 & $\mathrm{FeCl}_{2}$ & 75 & 58 \\
8 & $\mathrm{FeCl}_{3}$ & 5 & 73 & 58 \\
9 & $\mathrm{FeCl}_{3}$ & 1 & 77 & 49 \\
10 & $\mathrm{FeCl}_{3}$ & 2 & 71 & 63 \\
11 & $\mathrm{CuCl}_{2} \cdot 2 \mathrm{H}_{2} \mathrm{O}$ & 5 & 77 & 61 \\
12 & $\mathrm{CuCl}_{2} \cdot 2 \mathrm{H}_{2} \mathrm{O}$ & 1 & 72 & 43 \\
13 & $\mathrm{CuCl}_{2} \cdot 2 \mathrm{H}_{2} \mathrm{O}$ & 2 & 69 & 59 \\
14 & $\mathrm{CuSO}_{4} \cdot 5 \mathrm{H}_{2} \mathrm{O}$ & 5 & 74 & 70 \\
15 & $\mathrm{CuSO}_{4} \cdot 5 \mathrm{H}_{2} \mathrm{O}$ & 1 & 82 & 69 \\
\hline $\mathrm{CuSO}_{4} \cdot 5 \mathrm{H}_{2} \mathrm{O}$ & 2 & 87 & \\
\hline
\end{tabular}

${ }^{a}$ Reaction conditions: 3a $(0.5 \mathrm{mmol}), \mathbf{5 a}(2 \mathrm{mmol}), \mathrm{Ru}_{3}(\mathrm{CO})_{12}(7 \mathrm{~mol} \%)$, co-catalyst, 2,2-dimethylpropane-1,3-diol $(0.25 \mathrm{mmol}), 0.5 \mathrm{~cm}^{3}{ }_{o}$ xylene, $135^{\circ} \mathrm{C}$, stirred for $36 \mathrm{~h}$ under argon conditions in an open vial

${ }^{\mathrm{b}}$ Conversion based on GC analysis with respect to $\mathbf{3 a}$ and $\mathbf{4 a}$ (dodecane as internal standard)

c Yield determined by GC analysis with respect to $\mathbf{4 a}$ (dodecane as internal standard) using a calibration curve 
Table 3 Scope of mono-arylations with different arylboronate esters $\mathbf{5}^{\text {a }}$

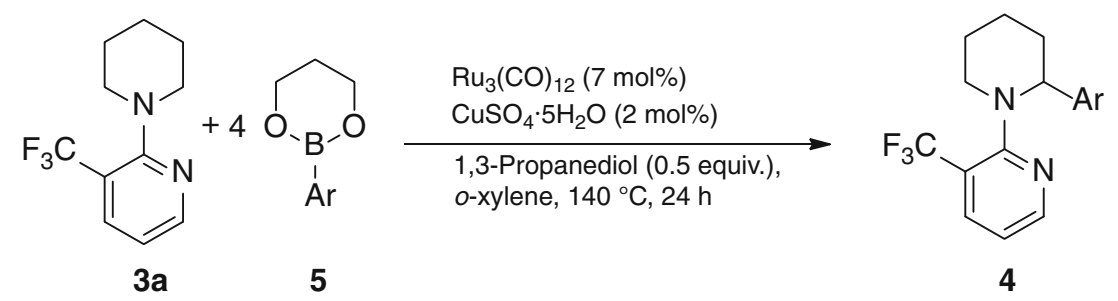

\begin{tabular}{|c|c|c|c|}
\hline Entry & $\mathrm{Ar}$ & Product & Yield $/ \%^{\mathrm{b}}$ \\
\hline 1 & $\mathrm{C}_{6} \mathrm{H}_{5}$ & $4 a$ & 60 \\
\hline 2 & 4-Me- $\mathrm{C}_{6} \mathrm{H}_{4}$ & $4 b$ & 47 \\
\hline 3 & $4-t-\mathrm{Bu}-\mathrm{C}_{6} \mathrm{H}_{4}$ & $4 c$ & 50 \\
\hline 4 & 4-F- $\mathrm{C}_{6} \mathrm{H}_{4}$ & $4 d$ & 43 \\
\hline 5 & $4-\mathrm{Cl}-\mathrm{C}_{6} \mathrm{H}_{4}$ & $4 e$ & 34 \\
\hline 6 & 4-MeO- $\mathrm{C}_{6} \mathrm{H}_{4}$ & $4 f$ & $16^{\mathrm{c}}$ \\
\hline 7 & $4-\mathrm{CF}_{3}-\mathrm{C}_{6} \mathrm{H}_{4}$ & $4 g$ & 40 \\
\hline 8 & $4-\mathrm{CN}-\mathrm{C}_{6} \mathrm{H}_{4}$ & $4 \mathrm{~h}$ & n.i. \\
\hline 9 & $4-\mathrm{NO}_{2}-\mathrm{C}_{6} \mathrm{H}_{4}$ & $4 i$ & n.i. \\
\hline 10 & $3-\mathrm{Me}-\mathrm{C}_{6} \mathrm{H}_{4}$ & $4 j$ & 49 \\
\hline 11 & $3-\mathrm{Cl}-\mathrm{C}_{6} \mathrm{H}_{4}$ & $4 \mathbf{k}$ & 39 \\
\hline 12 & 2-Me- $\mathrm{C}_{6} \mathrm{H}_{4}$ & 41 & n.i. \\
\hline
\end{tabular}

${ }^{a}$ Reaction conditions: 3a $(0.5 \mathrm{mmol}), 5(2 \mathrm{mmol}), \mathrm{Ru}_{3}(\mathrm{CO})_{12}(7 \mathrm{~mol} \%), \mathrm{CuSO}_{4} \cdot 5 \mathrm{H}_{2} \mathrm{O}(2 \mathrm{~mol} \%), 1,3$-propanediol $(0.25 \mathrm{mmol}), 0.5 \mathrm{~cm}{ }^{3}$ $o$-xylene, $140{ }^{\circ} \mathrm{C}$, stirred for $24 \mathrm{~h}$ under argon conditions in an open vial

${ }^{b}$ Isolated yield after flash column chromatography; those examples with low or no conversion were not isolated (n.i.)

c Bis-arylated product was obtained in addition; additional purification by preparative TLC

since instead of having to separate mono-arylated from bis-arylated compound, the mono-arylated compound now has to be separated from starting material due to incomplete conversion. However, separation of substrate from mono-arylated product is very facile, whereas separation of mono- and bis-arylated products is very difficult.

With the optimized conditions in hand, we explored the scope of the reaction. For piperidine, different aryl groups were introduced and the results are shown in Table 3. The best result could be achieved for the unsubstituted phenyl group, yielding $60 \%$ of the desired product $4 \mathbf{a}$ (Table 3 , entry 1). Also in the presence of electron-donating alkyl groups as substituents in para- or meta-position, yields in the range of $50 \%$ were obtained for $\mathbf{4 b}, \mathbf{4 c}$, and $\mathbf{4 j}$ (Table 3 , entries 2, 3, 10). The presence of a substituent in ortho-position decreased the conversion dramatically, most likely due to steric hindrance (Table 3 , entry $12, \mathbf{4 l}$ ). Boronic acid esters bearing electron-withdrawing groups gave lower yields (Table 3, entries 4, 5, 7, 11). Nitrogen-containing electron-withdrawing groups such as nitro or cyano were not tolerated (Table 3, entries 8,9 ). This may be due to complexation of the catalyst at these functional groups, making the catalyst unavailable for the desired transformation. The trend for electron-withdrawing substituents to give lower and electron-withdrawing coordinating substituents to give no conversion was already observed by us in the previously reported direct arylation of benzylamines [37-39]. The result for the $p$-methoxy substituent was surprising (Table 3, entry 6). Compound $\mathbf{4 f}$ could be isolated with yield of only $16 \%$, because to some extent also the bis-arylated product was formed. This was the only case where bis-arylation was observed for piperidine, when employing a substituted pyridine directing group. To separate the two compounds, preparative thin-layer chromatography (TLC) had to be performed additionally after flash column chromatography. This accounts for the low yield and shows the isolation problems with unselective reactions. A pure fraction of bis-arylated product could actually not be obtained. The mono-arylated product $\mathbf{4 f}$ seems to promote the second arylation step. This hypothesis was tested by subjecting isolated $\mathbf{4 f}$ to the arylation conditions. Indeed, formation of the bis-arylated compound could be observed by GC-mass spectrometry (MS), albeit only in small amounts $(\sim 10 \%)$.

The scope of the reaction was also investigated regarding different saturated amines (Table 4). In the case of 2-methyl-substituted piperidine 3b (Table 4, entry 1), the conversion dropped, as expected, to only $36 \%$ due to steric hindrance. When the arylation was conducted on 
Table 4 Scope of monoarylations with different saturated cyclic amines $\mathbf{3}^{\mathrm{a}}$
${ }^{\text {a }}$ Reaction conditions: $\mathbf{3}$ $(0.5 \mathrm{mmol}), \mathbf{5 a}(2 \mathrm{mmol})$, $\mathrm{Ru}_{3}(\mathrm{CO})_{12}(7 \mathrm{~mol} \%)$ $\mathrm{CuSO}_{4} \cdot 5 \mathrm{H}_{2} \mathrm{O}(2 \mathrm{~mol} \%), 1,3-$ propanediol $(0.25 \mathrm{mmol})$, $0.5 \mathrm{~cm}^{3} o$-xylene, $140{ }^{\circ} \mathrm{C}$, stirred for $24 \mathrm{~h}$ under argon conditions in an open vial

b Isolated yield after flash column chromatography; those examples with low or no conversion were not isolated (n.i.)

c Bis-arylated product was obtained in addition

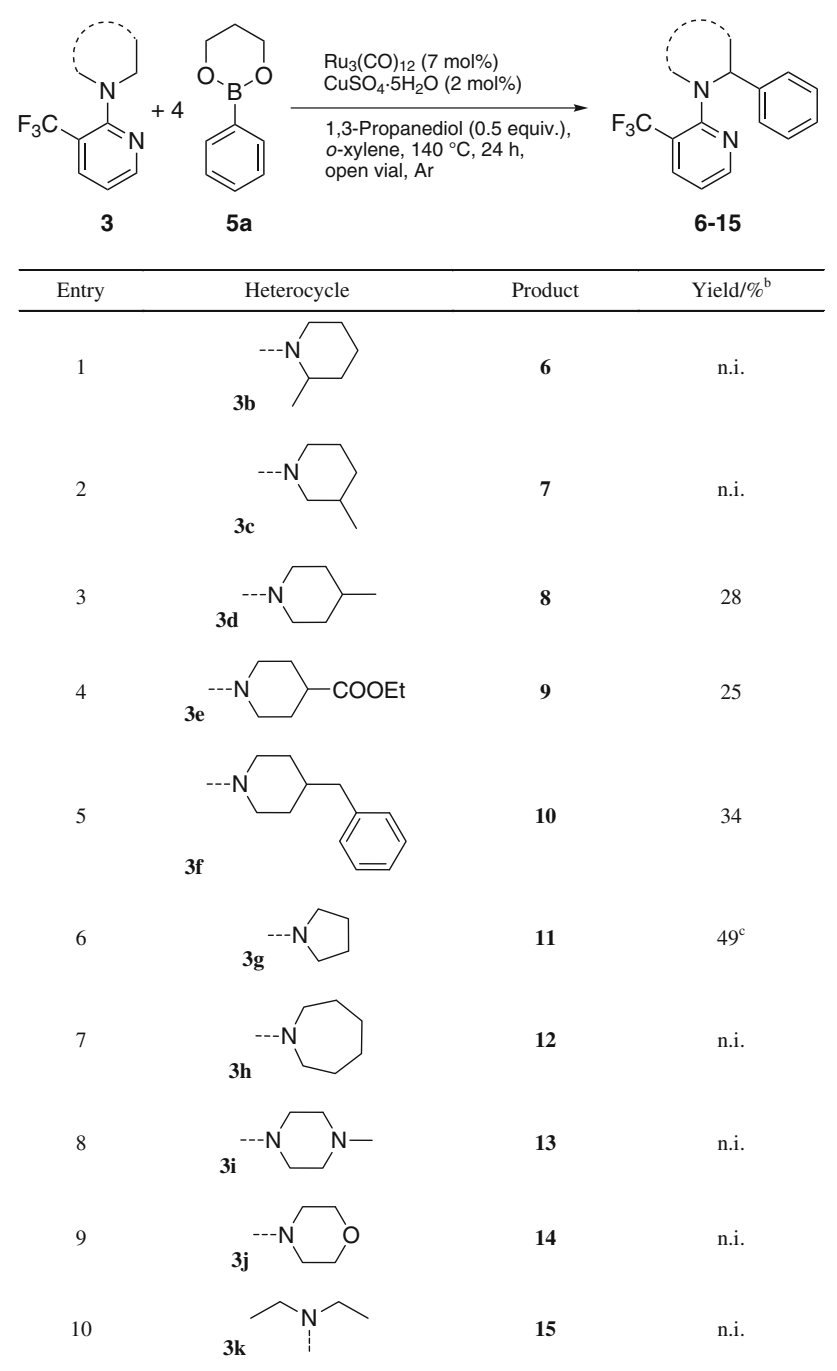

3-methyl-substituted piperidine 3c (entry 2), four isomers could be observed on GC-MS, which indicated that, in addition to the expected 2,5-substituted compound, also a 2,3-substituted compound was synthesized, both in cis and trans conformation. Not surprisingly, the isomers could not be separated by flash column chromatography. Overall, the yield was $30 \%$. For 4-substituted piperidines (Table 4, entries 3-5), yields between 25 and $34 \%$ were obtained. In all cases only one isomer was observed and isolated. ${ }^{1} \mathrm{H}$ nuclear magnetic resonance (NMR) signal patterns and coupling constants revealed that the aryl group in $\mathbf{8}$ is cis to the methyl group in 4-position. The products of the other reactions were assigned as the cis-isomers by analogy. Compared with piperidine, pyrrolidine 3g (Table 4, entry 6) showed higher conversion, but due to the different geometry of the ring, the trifluoromethyl group was not as effective in preventing bis-arylation (mono:bis $=1: 0.35$ on GC-MS). The mono-arylated compound $\mathbf{1 1}$ was obtained in $49 \%$ yield, but the bis-arylated product could not be obtained in pure form. Azepane (3h), piperazine (3i), and morpholine (3j) substrates (Table 4, entries 7-9) gave only low conversion, and the corresponding products were not isolated. The loss of reactivity for $\mathbf{3 i}$ and $\mathbf{3} \mathbf{j}$ may be explained by complexation of the catalyst to the heteroatoms. The only open-chain saturated amine (Table 4, entry 10) showed nearly no conversion at all.

As the reaction does not seem to be very tolerant regarding different rings, it was hypothesized that a specific geometry seems to be essential. Therefore, energy-minimization calculations were conducted for $\mathbf{3 a}, \mathbf{3 b}, \mathbf{3 c}, \mathbf{3 d}$, 3g, 3i, and 3j. The six-membered rings, except for the 2-substituted piperidine $\mathbf{3 b}$, all have rather similar geometry according to the calculations. As shown in Fig. 1 for 3a, they all have a slightly twisted boat conformation at the piperidine core. Especially the piperidine ring of $\mathbf{3 a}$ and the 4-substituted piperidine ring of 3d show very similar properties, and therefore the difference in yield could not be explained by the calculated geometries of these starting materials. A more conclusive result could have been obtained by calculating the corresponding $\mathrm{Ru}$ complexes 


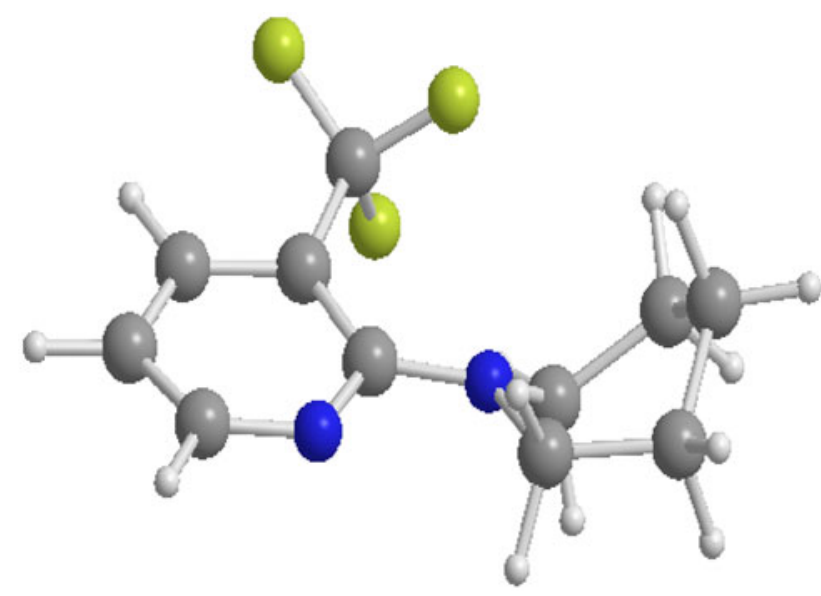

Fig. 1 Optimized PBE1PBE geometry of the equilibrium structure of 3a

formed during the reaction. However, since the nature of the active catalyst species is not known entirely, no such calculations could be conducted.

Finally, cleavage of the directing group was investigated. Initially, it was attempted to cleave the directing group via a method reported by Maes and coworkers [36]. They subjected the mono-arylated product (2-phenyl-1pyridin-2-yl)piperidine to Pd-catalyzed hydrogenation $\left(\mathrm{Pd} / \mathrm{C}, 1\right.$ atm $\mathrm{H}_{2}, \mathrm{HCl}, i$-PrOH) and subsequent $\mathrm{NH}_{2} \mathrm{NH}_{2} /$ $\mathrm{AcOH}$ treatment, which had already been used by Sames and coworkers [35], to cleave the pyrroline directing group. The same conditions were applied to 2-phenyl-1-(3-trifluoromethylpyridin-2-yl)piperidine (4a), but the reported protocol was not successful. It turned out that hydrogenation using $\mathrm{Pd} / \mathrm{C}$ as catalyst was not working in presence of the $\mathrm{CF}_{3}$ group on pyridine. On changing the hydrogenation catalyst to $\mathrm{PtO}_{2}$ hydrate, almost pure intermediate 16 was obtained after basic extraction. For further purification, the crude product was dissolved in $\mathrm{CH}_{2} \mathrm{Cl}_{2}$ and silica gel was added before the solvent was evaporated. This procedure was undertaken to subject the compound to column chromatography as solid. Interestingly, not only the desired product 2-phenyl-1-[3-(trifluoromethyl)-3,4,5,6-tetrahydropyridin-2-yl]piperidine (16) could be obtained in yield of $12 \%$ after purification, but also the product 17 lacking the trifluoromethyl group was isolated, in fact at much higher yield of $47 \%$. Obviously, this compound was generated during column chromatography, as it was not detected by GC-MS or ${ }^{1} \mathrm{H}$ NMR of the crude product. Hence, intentional formation of 17 from 16 was attempted. Crude 16 was diluted in $\mathrm{CH}_{2} \mathrm{Cl}_{2}$ and stirred in the presence of approximately fivefold weight of silica gel in a closed vial at $50{ }^{\circ} \mathrm{C}$. After $2.5 \mathrm{~h}$, GC-MS showed full conversion to 2-phenyl1-(3,4,5,6-tetrahydropyridin-2-yl)piperidine (17). To the best of our knowledge, this interesting detrifluoromethylation mediated by silica gel is unprecedented in the literature.
Both 16 (as crude material) and $\mathbf{1 7}$ were subjected to the cleavage conditions of $\mathrm{NH}_{2} \mathrm{NH}_{2} / \mathrm{AcOH}(2.5 / 0.7 \mathrm{M}$ in EtOH) at $120^{\circ} \mathrm{C}$ for $2 \mathrm{~h}$ in a closed vial, but only the reaction of $\mathbf{1 7}$ gave the desired product 2-phenylpiperidine (18) as detected by GC-MS and ${ }^{1} \mathrm{H}$ NMR of the crude product after basic extraction. Also other reaction parameters (changing the acid to trifluoroacetic acid, increasing the reaction time or temperature) to cleave the reduced directing group from $\mathbf{1 6}$ did not lead to formation of $\mathbf{1 8}$. Still, a new cleavage protocol was developed as shown in Scheme 3, providing the desired product 18 in $47 \%$ yield. Hence, our deprotection protocol is competitive to the previously published removal procedure of the unsubstituted pyridine directing group, which was also cleaved in $47 \%$ overall yield [36].

We propose the following mechanism for cleavage of the trifluoromethyl group (Scheme 4): Substrate 16 reacts with a free O-H group at the surface of silica gel to form 17, and the triflouromethyl group is bound to silica gel. Next, water present in silica gel hydrolyzes the newly formed $\mathrm{O}-\mathrm{CF}_{3}$ bond and trifluoromethanol is released, which then decomposes to carbonyl difluoride and hydrogen fluoride rapidly. This decomposition is described in the literature [41] to occur already at $-20{ }^{\circ} \mathrm{C}$, leading to gaseous compounds which can then not be detected using standard analytic techniques. The formation of gaseous compounds is supported by infrared (IR) analysis of the remaining silica gel after the deprotection, where no bands specific for $\mathrm{C}-\mathrm{F}$ bonds were detected.

In conclusion, saturated cyclic amines could be monoarylated in $\alpha$-position by selective transition-metal-catalyzed $\mathrm{C}-\mathrm{H}$ activation. Best results were obtained for piperidine. A number of different arylboronate esters were accepted in this reaction. For substituted piperidines the yields decreased and further dropped for all other saturated amines, with the exception of pyrrolidine. In this case, however, the different ring geometry led to some bis-arylation. Still, since purification problems between mono- and bis-arylated compounds can be avoided, the protocol offers significant potential in the synthesis of mono-arylated piperidines. For cleavage of the directing group, a modified protocol was developed, resulting in good yield. This interesting method takes advantage of an unprecedented $\mathrm{CF}_{3}$ cleavage under very mild conditions. Further exploration of the detrifluoromethylation may be of significant interest to the synthetic community and will be conducted in the near future.

\section{Experimental}

Unless otherwise noted chemicals were purchased from commercial suppliers and were used without further purification. Flash column chromatography was performed 
Scheme 3<smiles>FC(F)(F)c1cccnc1N1CCCCC1c1ccccc1</smiles>

$4 a$
$\mathrm{PtO}_{2}$ hydrate $(5 \mathrm{~mol} \%)$, $\mathrm{H}_{2}$ (1 atm), $\mathrm{HCl}, \mathrm{PrOH}$

$\mathrm{RT}, 14 \mathrm{~h}$<smiles>FC(F)(F)C1CCCN=C1N1CCCCC1c1ccccc1</smiles>

16 $50^{\circ} \mathrm{C}, 2.5 \mathrm{~h}$,<smiles>c1ccc(C2CCCCN2)cc1</smiles>

Overall yield $47 \%$

18
Silica gel DCM, closed vial \begin{tabular}{l}
$\mathrm{NH}_{2} \mathrm{NH}_{2} \cdot \mathrm{H}_{2} \mathrm{O}$ \\
$\mathrm{AcOH}, i-\mathrm{PrOH}$ \\
\hline $120^{\circ} \mathrm{C}, 2.5 \mathrm{~h}$
\end{tabular}

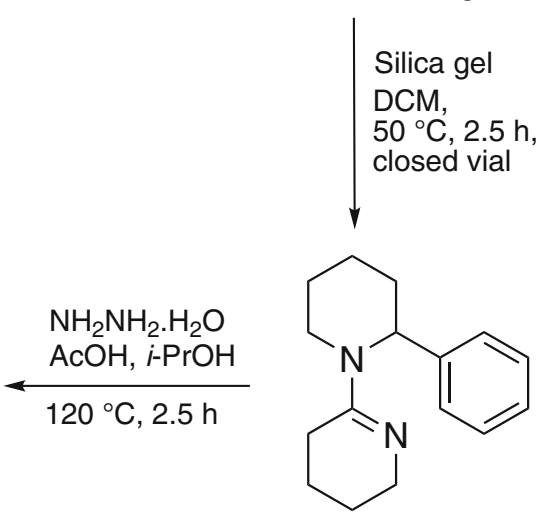

17

\section{Scheme 4}

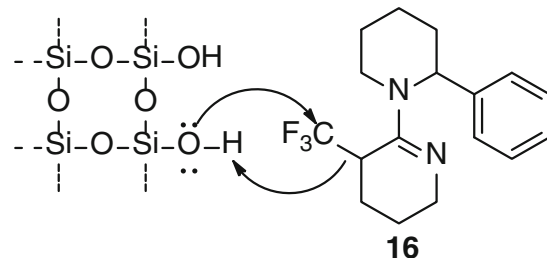<smiles>CCCCCC</smiles><smiles>C[Si]1(C)O[Si](C)(C)O[Si](C)(OC(F)(F)F)O[Si](C)(C)O1</smiles><smiles>[CH-]1CCC1</smiles>

$+$<smiles>c1ccc(C2CCCCN2C2=NCCCC2)cc1</smiles>
$+\mathrm{H}_{2} \mathrm{O}$

17

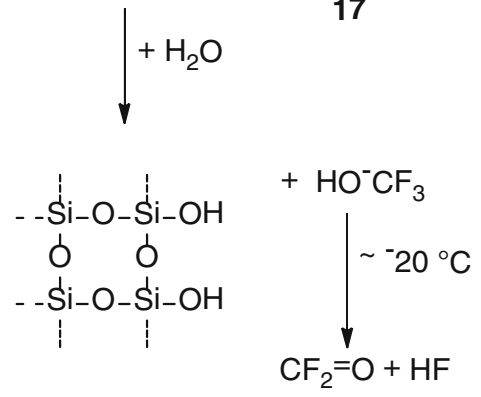

on silica gel 60 from Merck (40-63 $\mu \mathrm{m})$, using a Sepacore medium pressure liquid chromatography (MPLC) system from Büchi equipped with an ultraviolet (UV) light detector. TLC analysis was done with precoated aluminumbacked plates (silica gel 60 F254, Merck). Preparative TLC was performed on $20 \times 20 \mathrm{~cm}, 1,000 \mu \mathrm{m}$ thin-layer chromatography plates. Signals were visualized with UV light $(254 \mathrm{~nm})$. GC analyses were conducted on a Trace GC (Thermo Finnigan) using a BGB-5 (30 m $\times 0.32 \mathrm{~mm}$ i.d., $1.0 \mu \mathrm{m}$ film thickness) polysiloxane (5\% diphenyl-, $95 \%$ dimethylpolysiloxane) capillary column. The oven temperature program was $100{ }^{\circ} \mathrm{C}(2 \mathrm{~min}) / 18{ }^{\circ} \mathrm{C}$ per min/ $280{ }^{\circ} \mathrm{C}(5 \mathrm{~min})$. GC-MS analyses were conducted on a DSQ II GC-MS with Focus GC (Thermo Scientific), using a BGB-5 (30 $\mathrm{m} \times 0.25 \mathrm{~mm}$ i.d., $0.25 \mu \mathrm{m}$ film thickness) polysiloxane (5\% diphenyl-, $95 \%$ dimethylpolysiloxane) capillary column. The oven temperature program was $100{ }^{\circ} \mathrm{C} \quad(2 \mathrm{~min}) / 18{ }^{\circ} \mathrm{C}$ per $\min / 280{ }^{\circ} \mathrm{C} \quad(3 \mathrm{~min})$, unlike otherwise stated. Source and transfer line were set at 250 and $280{ }^{\circ} \mathrm{C}$, respectively.

High-resolution mass spectroscopy measurements were carried out by E. Rosenberg at the Institute for Chemical 
Technologies and Analytics, Vienna University of Technology. All samples were analyzed by liquid chromatography (LC)-ion trap (IT)-time of flight (TOF)-MS with electrospray (ES) ionization and atmospheric-pressure chemical ionization (APCI) in positive ion detection mode, recording only $\mathrm{MS}^{(1)}$ spectra. The exact mass was used to calculate the elemental composition of the analytes from the quasimolecular ion $[\mathrm{M}+\mathrm{H}]^{+}$for the evaluation. Instrumental parameters: Shimadzu Prominence HPLC, consisting of: solvent degassing unit (DGU-20 A3), binary gradient pump ( $2 \times$ LC-20AD), auto-injector (SIL-20A), column oven (CTO-20AC), control module (CBM-20A), and diode array detector (SPD-M20A). Chromatography: column: Phenomenex Kinetex $\operatorname{ODS}(3), 30 \times 4.6 \mathrm{~mm}$, $2.6 \mu \mathrm{m}$ core-shell particles, operated at $40{ }^{\circ} \mathrm{C}$; gradient: 0 min: $70 \%$ A, $30 \% \mathrm{~B}(1 \mathrm{~min})$; linear gradient to $5 \mathrm{~min}$ to $10 \%$ A, $90 \%$ B (hold until $10 \mathrm{~min}$ ); at 10.01 min back to $70 \%$ A, $30 \%$ B (hold until $12.0 \mathrm{~min}) ; \mathrm{A}: \mathrm{H}_{2} \mathrm{O}(0.1 \%$ v/v $\mathrm{HCOOH}), \mathrm{B}:$ acetonitrile $(0.1 \% \mathrm{v} / \mathrm{v} \mathrm{HCOOH})$; flow: $0.5 \mathrm{~cm}^{3} / \mathrm{min}$; injection volume: $0.5 \mathrm{~mm}^{3}$. MS parameters: MS parameters as in autotune. Data recorded with detector value at autotune value. Scan range: $100-1,000 \mathrm{amu}$ for MS (PI) detection. ES ionization: curved desolvation line (CDL) temperature: $200{ }^{\circ} \mathrm{C}$, heating block temperature: $200{ }^{\circ} \mathrm{C}$.

Melting points were recorded using a Kofler-type Leica Galen III micro hot-stage microscope. Microwave reactions were performed on a BIOTAGE Initiator 60 microwave unit. The reported times are hold times. NMR spectra were recorded from $\mathrm{CDCl}_{3}$ solutions on a Bruker AC $200(200 \mathrm{MHz})$ or a Bruker DRX $400(400 \mathrm{MHz})$ spectrometer (as indicated), using the solvent peak $\left[\mathrm{CDCl}_{3}\right.$ : $\left.\delta=7.26 \mathrm{ppm}\left({ }^{1} \mathrm{H}\right), \delta=77.16 \mathrm{ppm}\left({ }^{13} \mathrm{C}\right)\right]$ and tetramethylsilane (TMS) as reference. ${ }^{13} \mathrm{C}$ spectra were run in proton-decoupled mode, and in addition some spectra were also recorded as distortionless enhanced polarization transfer (DEPT) or attached proton test (APT).

\section{General procedure A}

2-Chloro-3-(trifluoromethyl)pyridine (1, 1 equiv.), amine 2 ( 2 or 3 equiv.), $\mathrm{K}_{2} \mathrm{CO}_{3}$ (2 equiv.), and acetonitrile were placed in a microwave vial, a round-bottom flask with a reflux condenser, or a closed $8-\mathrm{cm}^{3}$ vial, all equipped with a magnetic stirring bar (see respective compound for the reaction vessel used). The reaction mixture was heated, either in the microwave reactor or conventionally, and monitored by TLC and GC-MS. When reaction control showed full consumption of the starting material or no further progress, the mixture was cooled to room temperature and filtered, and the solvent was evaporated. The residue was purified by silica gel flash column chromatography to give the desired product $\mathbf{3}$.

\section{1-(3-Trifluoromethylpyridin-2-yl)piperidine}

$\left(3 \mathrm{a}, \mathrm{C}_{11} \mathrm{H}_{13} \mathrm{~F}_{3} \mathrm{~N}_{2}\right)$

Prepared according to general procedure A starting from $3.630 \mathrm{~g} 1(20 \mathrm{mmol})$ and $3.406 \mathrm{~g}$ piperidine $(\mathbf{2 a}, 40 \mathrm{mmol}$, 2 equiv.) using $40 \mathrm{~cm}^{3}$ acetonitrile. Conditions: roundbottom flask with reflux condenser, reflux, $24 \mathrm{~h}$. Yield: $79 \% \quad(3.634 \mathrm{~g})$; colorless oil; ${ }^{1} \mathrm{H}$ NMR $\left(\mathrm{CDCl}_{3}\right.$, $200 \mathrm{MHz}): \delta=1.51-1.75(\mathrm{~m}, 6 \mathrm{H}), 3.20-3.25(\mathrm{~m}, 4 \mathrm{H})$, $6.92(\mathrm{dd}, J=7.7 \mathrm{~Hz}, 4.7 \mathrm{~Hz}, 1 \mathrm{H}), 7.83(\mathrm{dd}, J=7.7 \mathrm{~Hz}$, $1.7 \mathrm{~Hz}, 1 \mathrm{H}), 8.40(\mathrm{br} \mathrm{d}, J=3.7 \mathrm{~Hz}, 1 \mathrm{H}) \mathrm{ppm} ;{ }^{13} \mathrm{C} \mathrm{NMR}$ $\left(\mathrm{CDCl}_{3}, 50 \mathrm{MHz}\right): \delta=24.4,26.0,51.9,116.1,116.6(\mathrm{q}$, $J=31.3 \mathrm{~Hz}), \quad 124.1 \quad(\mathrm{q}, \quad J=272.4 \mathrm{~Hz}), \quad 137.2 \quad(\mathrm{q}$, $J=5.1 \mathrm{~Hz}), \quad 150.9, \quad 160.5 \mathrm{ppm} ; \quad$ HR-MS: $[\mathrm{M}+\mathrm{H}]^{+}$ $\mathrm{m} / \mathrm{z}($ predicted $)=307.1417, \mathrm{~m} / \mathrm{z}($ measured $)=307.1409$.

\section{2-Methyl-1-[3-(trifluoromethyl)pyridin-2-yl]piperidine}

(3b, $\mathrm{C}_{12} \mathrm{H}_{15} \mathrm{~F}_{3} \mathrm{~N}_{2}$ )

Prepared according to general procedure A starting from $363 \mathrm{mg} 1(2 \mathrm{mmol})$ and $594 \mathrm{mg}$ 2-methylpiperidine (2b, $6 \mathrm{mmol}, 3$ equiv.) using $4 \mathrm{~cm}^{3}$ acetonitrile. Conditions: microwave, $180{ }^{\circ} \mathrm{C}, \quad 3.5 \mathrm{~h}$. Yield: $26 \% \quad(128.3 \mathrm{mg})$; slightly yellow oil; ${ }^{1} \mathrm{H}$ NMR $\left(\mathrm{CDCl}_{3}, \quad 200 \mathrm{MHz}\right)$ : $\delta=0.84 \quad(\mathrm{~d}, \quad 3 \mathrm{H}, \quad J=6.2 \mathrm{~Hz}), \quad 1.33-1.84 \quad(\mathrm{~m}, \quad 6 \mathrm{H})$, 2.74-2.86 (m, 1H), 2.99-3.09 (m, 1H), 3.36-3.52 (m, $1 \mathrm{H}), 7.12(\mathrm{dd}, J=7.8 \mathrm{~Hz}, 4.8 \mathrm{~Hz}, 1 \mathrm{H}), 7.97(\mathrm{dd}$, $J=7.8 \mathrm{~Hz}, 1.9 \mathrm{~Hz}, 1 \mathrm{H}), 8.57(\mathrm{dd}, J=4.7 \mathrm{~Hz}, 1.2 \mathrm{~Hz}$, 1H) $\mathrm{ppm} ;{ }^{13} \mathrm{C} \mathrm{NMR}\left(\mathrm{CDCl}_{3}, 50 \mathrm{MHz}\right): \delta=19.3,23.7$, 26.0, 33.8, 53.6, 54.2, 119.0, $122.3(\mathrm{q}, J=30.6 \mathrm{~Hz}), 123.5$ $(\mathrm{q}, \quad J=272.4 \mathrm{~Hz}), \quad 136.2 \quad(\mathrm{q}, \quad J=5.1 \mathrm{~Hz}), \quad 151.6$, 162.9 ppm; HR-MS: $[\mathrm{M}+\mathrm{H}]^{+} \quad \mathrm{m} / \mathrm{z} \quad$ (predicted) $=$ $245.1260, \mathrm{~m} / \mathrm{z}$ (measured) $=245.1257$.

\section{3-Methyl-1-[3-(trifluoromethyl)pyridin-2-yl]piperidine}

$\left(3 \mathbf{c}, \mathrm{C}_{12} \mathrm{H}_{15} \mathrm{~F}_{3} \mathrm{~N}_{2}\right.$ )

Prepared according to general procedure A starting from $363 \mathrm{mg} 1(2 \mathrm{mmol})$ and $396 \mathrm{mg}$ 3-methylpiperidine (2c, $4 \mathrm{mmol}, 2$ equiv.) using $4 \mathrm{~cm}^{3}$ acetonitrile. Conditions: microwave, $180{ }^{\circ} \mathrm{C}, 1.5 \mathrm{~h}$. Yield: $87 \%$ (423.6 mg); colorless oil; ${ }^{1} \mathrm{H} \mathrm{NMR}\left(\mathrm{CDCl}_{3}, 200 \mathrm{MHz}\right): \delta=0.92(\mathrm{~d}, 3 \mathrm{H}$, $J=6.4 \mathrm{~Hz}), 0.97-1.17(\mathrm{~m}, 1 \mathrm{H}), 1.59-1.89(\mathrm{~m}, 4 \mathrm{H}), 2.53$ $(\mathrm{dd}, J=12.2 \mathrm{~Hz}, 10.2 \mathrm{~Hz}, 1 \mathrm{H}), 2.75-2.88(\mathrm{~m}, 1 \mathrm{H})$, $3.48-3.57(\mathrm{~m}, 2 \mathrm{H}), 6.92(\mathrm{dd}, J=7.7 \mathrm{~Hz}, 4.8 \mathrm{~Hz}, 1 \mathrm{H})$, $7.83(\mathrm{dd}, J=7.7 \mathrm{~Hz}, 1.8 \mathrm{~Hz}, 1 \mathrm{H}), 8.41(\mathrm{dd}, J=4.7 \mathrm{~Hz}$, $1.3 \mathrm{~Hz}, 1 \mathrm{H}) \mathrm{ppm} ;{ }^{13} \mathrm{C} \mathrm{NMR}\left(\mathrm{CDCl}_{3}, 50 \mathrm{MHz}\right): \delta=19.2$, $25.4,31.1,33.0,51.6,58.5,116.1,116.5(\mathrm{q}, J=31.2 \mathrm{~Hz})$, $124.1(\mathrm{q}, J=272.4 \mathrm{~Hz}), 137.2(\mathrm{q}, J=5.1 \mathrm{~Hz}), 150.9$, 160.3 ppm; HR-MS: $[\mathrm{M}+\mathrm{H}]^{+} \quad \mathrm{m} / \mathrm{z} \quad$ (predicted) $=$ $245.1260, \mathrm{~m} / \mathrm{z}$ (measured) $=245.1252$.

\section{4-Methyl-1-[3-(trifluoromethyl)pyridin-2-yl]piperidine} $\left(\mathbf{3 d}, \mathrm{C}_{12} \mathrm{H}_{15} \mathrm{~F}_{3} \mathrm{~N}_{2}\right)$

Prepared according to general procedure A starting from $363 \mathrm{mg} 1$ (2 mmol) and $396 \mathrm{mg}$ 4-methylpiperidine (2d, 4 mmol, 2 equiv.) using $4 \mathrm{~cm}^{3}$ acetonitrile. Conditions: 
microwave, $180{ }^{\circ} \mathrm{C}, 1 \mathrm{~h}$. Yield: $90 \%$ (440.6 mg); colorless oil; ${ }^{1} \mathrm{H}$ NMR $\left(\mathrm{CDCl}_{3}, 200 \mathrm{MHz}\right): \delta=0.99(\mathrm{~d}, 3 \mathrm{H}$, $J=6.1 \mathrm{~Hz}), 1.25-1.75(\mathrm{~m}, 5 \mathrm{H}), 2.83-2.95(\mathrm{~m}, 2 \mathrm{H})$, $3.57-3.63(\mathrm{~m}, 2 \mathrm{H}), 6.92(\mathrm{dd}, J=7.7 \mathrm{~Hz}, 4.8 \mathrm{~Hz}, 1 \mathrm{H})$, 7.83 (dd, $J=7.8 \mathrm{~Hz}, 1.8 \mathrm{~Hz}, 1 \mathrm{H}), 8.40$ (br d, $J=3.6 \mathrm{~Hz}$, 1H) $\mathrm{ppm} ;{ }^{13} \mathrm{C} \mathrm{NMR}\left(\mathrm{CDCl}_{3}, 50 \mathrm{MHz}\right): \delta=21.9,30.9$, $34.3,51.3,116.1,116.6(\mathrm{q}, J=31.4 \mathrm{~Hz}), 124.1 \quad(\mathrm{q}$, $J=272.4 \mathrm{~Hz}), 137.2(\mathrm{q}, J=5.0 \mathrm{~Hz}), 150.8,160.4 \mathrm{ppm}$; HR-MS: $[\mathrm{M}+\mathrm{H}]^{+} \mathrm{m} / \mathrm{z} \quad($ predicted $)=245.1260, \quad \mathrm{~m} / \mathrm{z}$ (measured) $=245.1250$.

\section{Ethyl 1-[3-(trifluoromethyl)pyridin-2-yl]piperidine-4-} carboxylate $\left(3 \mathbf{e}, \mathrm{C}_{14} \mathrm{H}_{17} \mathrm{~F}_{3} \mathrm{~N}_{2} \mathrm{O}_{2}\right)$

Prepared according to general procedure A starting from $363 \mathrm{mg} 1(2 \mathrm{mmol})$ and $628 \mathrm{mg}$ ethyl piperidine-4-carboxylate (2c, $4 \mathrm{mmol}, 2$ equiv.) using $4 \mathrm{~cm}^{3}$ acetonitrile. Conditions: closed vial, $100{ }^{\circ} \mathrm{C}, 22.5 \mathrm{~h}$. Yield: $75 \%$ (454.5 mg); slightly yellow oil; ${ }^{1} \mathrm{H}$ NMR $\left(\mathrm{CDCl}_{3}\right.$, $200 \mathrm{MHz}): \quad \delta=1.28 \quad(\mathrm{t}, 3 \mathrm{H}, \quad J=7.1 \mathrm{~Hz}), \quad 1.25-1.75$ $(\mathrm{m}, \quad 4 \mathrm{H}), \quad 2.40-2.55(\mathrm{~m}, 1 \mathrm{H}), 2.89-3.03 \quad(\mathrm{~m}, 2 \mathrm{H})$, 3.54-3.63 (m, 2H), $7.13(\mathrm{q}, 2 \mathrm{H}, J=7.1 \mathrm{~Hz}), 6.98(\mathrm{dd}$, $J=7.7 \mathrm{~Hz}, 4.8 \mathrm{~Hz}, 1 \mathrm{H}), 7.85(\mathrm{dd}, J=7.8 \mathrm{~Hz}, 1.8 \mathrm{~Hz}$, $1 \mathrm{H}), 8.42(\mathrm{dd}, J=4.6 \mathrm{~Hz}, 1.4 \mathrm{~Hz}, 1 \mathrm{H}) \mathrm{ppm} ;{ }^{13} \mathrm{C} \mathrm{NMR}$ $\left(\mathrm{CDCl}_{3}, 50 \mathrm{MHz}\right): \delta=13.9,28.0,40.9,50.3,60.1,116.6$, $117.0(\mathrm{q}, J=31.4 \mathrm{~Hz}), 123.6(\mathrm{q}, J=272.6 \mathrm{~Hz}), 136.9(\mathrm{q}$, $J=5.0 \mathrm{~Hz}), 150.7,159.9,174.6$ ppm; HR-MS: $[\mathrm{M}+\mathrm{H}]^{+}$ $\mathrm{m} / \mathrm{z}($ predicted $)=303.1316, \mathrm{~m} / \mathrm{z}($ measured $)=303.1307$.

\section{4-Benzyl-1-[3-(trifluoromethyl)pyridin-2-yl]piperidine} (3f, $\mathrm{C}_{18} \mathrm{H}_{19} \mathrm{~F}_{3} \mathrm{~N}_{2}$ )

Prepared according to general procedure A starting from $363 \mathrm{mg} 1(2 \mathrm{mmol})$ and $700 \mathrm{mg}$ 4-benzylpiperidine (2f, $4 \mathrm{mmol}, 2$ equiv.) using $4 \mathrm{~cm}^{3}$ acetonitrile. Conditions: closed vial, $100{ }^{\circ} \mathrm{C}, 22.5 \mathrm{~h}$. Yield: $87 \%$ (556 mg); slightly yellow solid; m.p.: $56-59{ }^{\circ} \mathrm{C} ;{ }^{1} \mathrm{H} \quad \mathrm{NMR} \quad\left(\mathrm{CDCl}_{3}\right.$, $200 \mathrm{MHz}): \delta=1.32-1.76 \quad(\mathrm{~m}, \quad 5 \mathrm{H}), 2.60 \quad(\mathrm{~d}, \quad 2 \mathrm{H}$, $J=6.6 \mathrm{~Hz}), 2.78-2.90(\mathrm{~m}, 2 \mathrm{H}), 3.57-3.64(\mathrm{~m}, 2 \mathrm{H}), 6.92$ (dd, $J=7.7 \mathrm{~Hz}, 4.8 \mathrm{~Hz}, 1 \mathrm{H}), 7.16-7.34(\mathrm{~m}, 5 \mathrm{H}), 7.82(\mathrm{dd}$, $J=7.7 \mathrm{~Hz}, 1.8 \mathrm{~Hz}, 1 \mathrm{H}), 8.39(\mathrm{dd}, J=4.6 \mathrm{~Hz}, 1.5 \mathrm{~Hz}$, 1H) $\mathrm{ppm} ;{ }^{13} \mathrm{C} \mathrm{NMR}\left(\mathrm{CDCl}_{3}, 50 \mathrm{MHz}\right): \delta=32.3,38.0$, $43.3,51.2,116.3,116.6(\mathrm{q}, J=31.4 \mathrm{~Hz}), 124.1 \quad(\mathrm{q}$, $J=272.5 \mathrm{~Hz}), \quad 128.2, \quad 129.1,137.2(\mathrm{q}, \quad J=5.1 \mathrm{~Hz})$, 140.6, 150.9, $160.2 \mathrm{ppm}$; HR-MS: $[\mathrm{M}+\mathrm{H}]^{+} \mathrm{m} / \mathrm{z}$ (predicted $)=321.1573, \mathrm{~m} / \mathrm{z}$ (measured $)=321.1559$.

\section{1-[3-(trifluoromethyl)pyridin-2-yl]pyrrolidine \\ $\left(3 \mathrm{~g}, \mathrm{C}_{10} \mathrm{H}_{11} \mathrm{~F}_{3} \mathrm{~N}_{2}\right)$}

Prepared according to general procedure A starting from $1.089 \mathrm{~g} 1(6 \mathrm{mmol})$ and $853 \mathrm{mg}$ pyrrolidine $(\mathbf{2 g}, 12 \mathrm{mmol}$, 2 equiv.) using $12 \mathrm{~cm}^{3}$ acetonitrile. Conditions: roundbottom flask with reflux condenser, reflux, $48 \mathrm{~h}$. Yield: $84 \% \quad(1.0884 \mathrm{~g}) ;$ colorless oil; ${ }^{1} \mathrm{H}$ NMR $\left(\mathrm{CDCl}_{3}\right.$, $200 \mathrm{MHz}): \delta=1.88-2.01(\mathrm{~m}, 4 \mathrm{H}), 3.56-3.62(\mathrm{~m}, 4 \mathrm{H})$, $6.62(\mathrm{dd}, J=7.7 \mathrm{~Hz}, 4.7 \mathrm{~Hz}, 1 \mathrm{H}), 7.78(\mathrm{dd}, J=7.8 \mathrm{~Hz}$,
$1.7 \mathrm{~Hz}, 1 \mathrm{H}), 8.27(\mathrm{dd}, J=4.4 \mathrm{~Hz}, 1.2 \mathrm{~Hz}, 1 \mathrm{H}) \mathrm{ppm} ;{ }^{13} \mathrm{C}$ NMR $\left(\mathrm{CDCl}_{3}, 50 \mathrm{MHz}\right): \delta=25.6,49.5(\mathrm{q}, J=3.2 \mathrm{~Hz})$, $108.6(\mathrm{q}, J=32.2 \mathrm{~Hz}), 110.9,124.5(\mathrm{q}, J=271.2 \mathrm{~Hz})$, 136.9 (q, $J=6.2 \mathrm{~Hz}), \quad 150.6, \quad 154.9$ ppm; HR-MS: $[\mathrm{M}+\mathrm{H}]^{+} \mathrm{m} / \mathrm{z}$ (predicted) $=217.0947, \mathrm{~m} / \mathrm{z}$ (measured) $=$ 217.0945 .

\section{1-[3-(trifluoromethyl)pyridin-2-yl]hexahydroazepine}

(3h, $\left.\mathrm{C}_{12} \mathrm{H}_{15} \mathrm{~F}_{3} \mathrm{~N}_{2}\right)$

Prepared according to general procedure A starting from $1.452 \mathrm{~g} 1(8 \mathrm{mmol})$ and $1.584 \mathrm{~g}$ hexahydroazepine $(\mathbf{2 h}$, $16 \mathrm{mmol}, 2$ equiv.) using $16 \mathrm{~cm}^{3}$ acetonitrile. Conditions: round-bottom flask with reflux condenser, reflux, $65 \mathrm{~h}$. Yield: $86 \%$ (1.6728 g); colorless oil; ${ }^{1} \mathrm{H}$ NMR $\left(\mathrm{CDCl}_{3}\right.$, $200 \mathrm{MHz}): \delta=1.54-1.66(\mathrm{~m}, 4 \mathrm{H}), 1.76-1.89(\mathrm{~m}, 4 \mathrm{H})$, $3.57(\mathrm{t}, J=5.6 \mathrm{~Hz}, 4 \mathrm{H}), 6.72(\mathrm{dd}, J=7.7 \mathrm{~Hz}, 4.6 \mathrm{~Hz}$, $1 \mathrm{H}), 7.77(\mathrm{dd}, J=7.8 \mathrm{~Hz}, 1.8 \mathrm{~Hz}, 1 \mathrm{H}), 8.29(\mathrm{dd}$, $J=4.3 \mathrm{~Hz}, 1.3 \mathrm{~Hz}, 1 \mathrm{H})$ ppm; ${ }^{13} \mathrm{C}$ NMR $\left(\mathrm{CDCl}_{3}\right.$, $200 \mathrm{MHz}): \delta=27.6,28.4,51.9(\mathrm{q}, J=2.2 \mathrm{~Hz}), 111.3$ $(\mathrm{q}, J=31.7 \mathrm{~Hz}), 116.3,124.4(\mathrm{q}, J=271.7 \mathrm{~Hz}), 137.5(\mathrm{q}$, $J=5.7 \mathrm{~Hz}), \quad 150.1, \quad 158.8$ ppm; $\quad$ HR-MS: $[\mathrm{M}+\mathrm{H}]^{+}$ $\mathrm{m} / \mathrm{z}($ predicted $)=245.1260, \mathrm{~m} / \mathrm{z}($ measured $)=245.1250$.

\section{1-Methyl-4-[3-(trifluoromethyl)pyridin-2-yl]piperazine $\left(3 i, \mathrm{C}_{11} \mathrm{H}_{14} \mathrm{~F}_{3} \mathrm{~N}_{3}\right)$}

Prepared according to general procedure A starting from $1.452 \mathrm{~g} 1(8 \mathrm{mmol})$ and $1.600 \mathrm{~g} \mathrm{1-methylpiperazine} \mathrm{(2i,}$ $16 \mathrm{mmol}, 2$ equiv.) using $16 \mathrm{~cm}^{3}$ acetonitrile. Conditions: round-bottom flask with reflux condenser, reflux, $65 \mathrm{~h}$. Yield: $83 \%$ (1.632 g); slightly yellow oil; ${ }^{1} \mathrm{H}$ NMR $\left(\mathrm{CDCl}_{3}, \quad 200 \mathrm{MHz}\right): \quad \delta=2.35 \quad(\mathrm{~s}, \quad 3 \mathrm{H}), \quad 2.56 \quad(\mathrm{t}$, $J=4.8 \mathrm{~Hz}, 4 \mathrm{H}), 3.35(\mathrm{t}, J=4.8 \mathrm{~Hz}, 4 \mathrm{H}), 6.95(\mathrm{dd}$, $J=7.7 \mathrm{~Hz}, 4.8 \mathrm{~Hz}, 1 \mathrm{H}), 7.84(\mathrm{dd}, J=7.8 \mathrm{~Hz}, 1.5 \mathrm{~Hz}$, $1 \mathrm{H}), 8.41(\mathrm{br} \mathrm{d}, J=4.8 \mathrm{~Hz}, 1 \mathrm{H}) \mathrm{ppm} ;{ }^{13} \mathrm{C} \mathrm{NMR}\left(\mathrm{CDCl}_{3}\right.$, $50 \mathrm{MHz}): \delta=46.1,50.4,55.1,116.3(\mathrm{q}, J=31.5 \mathrm{~Hz})$, $116.4,124.0(\mathrm{q}, J=272.6 \mathrm{~Hz}), 137.2(\mathrm{q}, J=5.1 \mathrm{~Hz})$, 150.9, 159.4 ppm; HR-MS: $[\mathrm{M}+\mathrm{H}]^{+} \mathrm{m} / z$ (predicted $)=$ $246.1213, \mathrm{~m} / \mathrm{z}$ (measured) $=246.1200$.

\section{1-[3-(trifluoromethyl)pyridin-2-yl]morpholine}

$\left(\mathbf{3 j}, \mathrm{C}_{10} \mathrm{H}_{11} \mathrm{~F}_{3} \mathrm{~N}_{2} \mathrm{O}\right.$ )

Prepared according to general procedure A starting from $182 \mathrm{mg} 1(1 \mathrm{mmol})$ and $174 \mathrm{mg}$ morpholine $(\mathbf{2 j}, 2 \mathrm{mmol}$, 2 equiv.) using $2 \mathrm{~cm}^{3}$ acetonitrile. Conditions: microwave, $180{ }^{\circ} \mathrm{C}, 1.5 \mathrm{~h}$. Yield: $63 \%$ (147.3 mg); colorless oil; ${ }^{1} \mathrm{H}$ NMR $\left(\mathrm{CDCl}_{3}, 200 \mathrm{MHz}\right): \delta=3.29(\mathrm{t}, J=4.6 \mathrm{~Hz}, 4 \mathrm{H})$, $3.84(\mathrm{t}, J=4.6 \mathrm{~Hz}, 4 \mathrm{H}), 7.01(\mathrm{dd}, J=7.8 \mathrm{~Hz}, 4.8 \mathrm{~Hz}$, $1 \mathrm{H}), 7.89(\mathrm{dd}, J=7.8 \mathrm{~Hz}, 1.7 \mathrm{~Hz}, 1 \mathrm{H}), 8.44(\mathrm{br} \mathrm{d}$, $J=4.3 \mathrm{~Hz}, 1 \mathrm{H}) \mathrm{ppm} ;{ }^{13} \mathrm{C} \mathrm{NMR}\left(\mathrm{CDCl}_{3}, 50 \mathrm{MHz}\right)$ : $\delta=51.1,66.9,117.0(\mathrm{q}, J=31.5 \mathrm{~Hz}), 117.1,123.9(\mathrm{q}$, $J=272.5 \mathrm{~Hz}), 137.2(\mathrm{q}, J=5.1 \mathrm{~Hz}), 151.1,159.5 \mathrm{ppm}$; HR-MS: $\quad[\mathrm{M}+\mathrm{H}]^{+} \mathrm{m} / \mathrm{z} \quad($ predicted $)=233.0896, \quad \mathrm{~m} / \mathrm{z}$ $($ measured $)=233.0888$. 
$N$-Ethyl-N-[3-(trifluoromethyl)pyridin-2-yl]ethanamine

(3k, $\mathrm{C}_{10} \mathrm{H}_{13} \mathrm{~F}_{3} \mathrm{~N}_{2}$ )

Prepared according to general procedure A starting from $363 \mathrm{mg} 1$ (2 mmol) and $439 \mathrm{mg} N$-ethylethanamine $(\mathbf{2 k}$, $6 \mathrm{mmol}, 3$ equiv.) using $4 \mathrm{~cm}^{3}$ acetonitrile. Conditions: microwave, $180{ }^{\circ} \mathrm{C}, 2 \mathrm{~h}$. Yield: $37 \%$ (160.8 mg); slightly yellow oil; ${ }^{1} \mathrm{H} \mathrm{NMR}\left(\mathrm{CDCl}_{3}, 200 \mathrm{MHz}\right): \delta=1.09(\mathrm{t}, 6 \mathrm{H}$, $J=7.1 \mathrm{~Hz}), \quad 3.30 \quad(\mathrm{q}, \quad 4 \mathrm{H}, \quad J=7.1 \mathrm{~Hz}), 6.93 \quad(\mathrm{dd}$, $J=7.8 \mathrm{~Hz}, 4.7 \mathrm{~Hz}, 1 \mathrm{H}), 7.85(\mathrm{dd}, J=7.8 \mathrm{~Hz}, 1.8 \mathrm{~Hz}$, $1 \mathrm{H}), 8.42(\mathrm{dd}, J=4.6 \mathrm{~Hz}, 1.2 \mathrm{~Hz}, 1 \mathrm{H}) \mathrm{ppm} ;{ }^{13} \mathrm{C} \mathrm{NMR}$ $\left(\mathrm{CDCl}_{3}, \quad 50 \mathrm{MHz}\right): \delta=12.8,46.1,116.1,117.6 \quad$ (q, $J=31.1 \mathrm{~Hz}), \quad 124.0 \quad(\mathrm{q}, \quad J=272.2 \mathrm{~Hz}), \quad 137.0 \quad(\mathrm{q}$, $J=5.3 \mathrm{~Hz}), \quad 150.6, \quad 159.9$ ppm; HR-MS: $[\mathrm{M}+\mathrm{H}]^{+}$ $\mathrm{m} / \mathrm{z}($ predicted $)=219.1104, \mathrm{~m} / \mathrm{z}($ measured $)=219.1009$.

\section{General procedure B}

An $8-\mathrm{cm}^{3}$ vial with a magnetic stirring bar and a screw cap with septum was charged with saturated cyclic amine $\mathbf{3}$ (0.5 mmol, 1 equiv.), arylboronate ester 5 (2 mmol, 4 equiv.), $22 \mathrm{mg} \quad \mathrm{Ru}_{3}(\mathrm{CO})_{12} \quad(0.035 \mathrm{mmol}, 7 \mathrm{~mol} \%)$, $19 \mathrm{mg}$ 1,3-propanediol (0.25 mmol, 0.5 equiv.), and $2.5 \mathrm{mg} \mathrm{CuSO} \cdot 5 \mathrm{H}_{2} \mathrm{O}(0.01 \mathrm{mmol}, 2 \mathrm{~mol} \%)$. The vial was evacuated and flushed with argon three times, and $0.5 \mathrm{~cm}^{3}$ $o$-xylene was added via syringe. Then, the vial was equipped with a balloon filled with argon, which was attached to a needle and plunged through the septum. The mixture was heated to $140{ }^{\circ} \mathrm{C}$ for $24 \mathrm{~h}$ in a heating block with a reflux condenser block on top. The reaction mixture was cooled to room temperature, and $2 \mathrm{~cm}^{3}$ EtOAc and $2 \mathrm{~cm}^{3}$ water were added to the reaction solution and agitated. The mixture was extracted three times with EtOAc. To achieve better phase separation, brine was added if necessary. The combined organic layers were dried over $\mathrm{Na}_{2} \mathrm{SO}_{4}$ and filtered, and the solvent was evaporated. The residue was purified by silica gel flash chromatography to give 4.

\section{2-Phenyl-1-[3-(trifluoromethyl)pyridin-2-yl]piperidine (4a, $\mathrm{C}_{17} \mathrm{H}_{17} \mathrm{~F}_{3} \mathrm{~N}_{2}$ )}

Yield: $60 \%$ (91.1 mg); colorless solid; m.p.: 92-94 ${ }^{\circ} \mathrm{C} ;{ }^{1} \mathrm{H}$ NMR $\left(\mathrm{CDCl}_{3}, 400 \mathrm{MHz}\right): \delta=1.52-1.61 \quad(\mathrm{~m}, 1 \mathrm{H})$, $1.72-1.90(\mathrm{~m}, 5 \mathrm{H}), 2.77$ (ddd, $J=11.5 \mathrm{~Hz}, 11.5 \mathrm{~Hz}$, $1.7 \mathrm{~Hz}, 1 \mathrm{H}), 3.32-3.36(\mathrm{~m}, 1 \mathrm{H}), 4.46$ (br d, $J=10.0 \mathrm{~Hz}$, $1 \mathrm{H}), 6.89(\mathrm{dd}, J=7.2 \mathrm{~Hz}, 5.0 \mathrm{~Hz}, 1 \mathrm{H}), 6.98-7.02(\mathrm{~m}, 1 \mathrm{H})$, $7.09(\mathrm{t}, J=7.6 \mathrm{~Hz}, 2 \mathrm{H}), 7.31(\mathrm{~d}, J=7.9 \mathrm{~Hz}, 2 \mathrm{H}), 7.75$ (dd, $J=7.8 \mathrm{~Hz}, 1.4 \mathrm{~Hz}, 1 \mathrm{H}), 8.32$ (br d, $J=4.7 \mathrm{~Hz}$, 1H) $\mathrm{ppm} ;{ }^{13} \mathrm{C} \mathrm{NMR}\left(\mathrm{CDCl}_{3}, 100 \mathrm{MHz}\right): \delta=24.9,26.1$, 35.6, 56.7, 64.3, 118.9, 121.7 (q, $J=30.9 \mathrm{~Hz}), 123.5$ (q, $J=272.6 \mathrm{~Hz}), 126.2,127.7,127.9,136.3(\mathrm{q}, J=5.2 \mathrm{~Hz})$, 144.3, 151.1, 162.5 ppm; HR-MS: $[\mathrm{M}+\mathrm{H}]^{+} \mathrm{m} / \mathrm{z}$ (predicted $)=307.1417, \mathrm{~m} / \mathrm{z}($ measured $)=307.1409$.
2-(p-Tolyl)-1-[3-(trifluoromethyl)pyridin-2-yl]piperidine (4b, $\mathrm{C}_{18} \mathrm{H}_{19} \mathrm{~F}_{3} \mathrm{~N}_{2}$ )

Yield: $47 \%$ (84.8 mg); slightly yellow solid; m.p.: 61-63 ${ }^{\circ} \mathrm{C} ;{ }^{1} \mathrm{H}$ NMR $\left(\mathrm{CDCl}_{3}, 400 \mathrm{MHz}\right): \delta=1.52-1.57$ (m, 1H), 1.71-1.90 (m, 5H), 2.17 (s, 3H), 2.76 (ddd, $J=11.5 \mathrm{~Hz}, 11.5 \mathrm{~Hz}, 2.5 \mathrm{~Hz}, 1 \mathrm{H}), 3.30-3.34(\mathrm{~m}, 1 \mathrm{H})$, $4.43(\mathrm{dd}, J=10.1 \mathrm{~Hz}, 2.8 \mathrm{~Hz}, 1 \mathrm{H}), 6.88-6.91(\mathrm{~m}, 3 \mathrm{H})$, $7.19(\mathrm{~d}, J=7.9 \mathrm{~Hz}, 2 \mathrm{H}), 7.75(\mathrm{dd}, J=7.8 \mathrm{~Hz}, 1.7 \mathrm{~Hz}$, $1 \mathrm{H}), 8.34$ (dd, $J=4.8 \mathrm{~Hz}, 1.5 \mathrm{~Hz}, 1 \mathrm{H}) \mathrm{ppm} ;{ }^{13} \mathrm{C} \mathrm{NMR}$ $\left(\mathrm{CDCl}_{3}, 100 \mathrm{MHz}\right): \delta=21.0,24.9,26.1,35.6,56.7,64.0$, $118.9,121.6(\mathrm{q}, J=30.9 \mathrm{~Hz}), 123.5(\mathrm{q}, J=272.7 \mathrm{~Hz}$,), 127.6, 127.8, 135.6, 136.3 (q, $J=5.2 \mathrm{~Hz}), \quad 141.3$, 151.1, 162.7 ppm; HR-MS: $[\mathrm{M}+\mathrm{H}]^{+} \mathrm{m} / \mathrm{z}$ (predicted) $=$ $321.1557, \mathrm{~m} / \mathrm{z}$ (measured) $=321.1564$.

2-(4-tert-Butylphenyl)-1-[3-(trifluoromethyl)pyridin-2-yl]piperidine (4c, $\mathrm{C}_{21} \mathrm{H}_{25} \mathrm{~F}_{3} \mathrm{~N}_{2}$ )

Yield: $50 \%$ (90.7 mg); colorless solid; m.p.: 93-96 ${ }^{\circ} \mathrm{C} ;{ }^{1} \mathrm{H}$ NMR $\left(\mathrm{CDCl}_{3}, 200 \mathrm{MHz}\right): \delta=1.20(\mathrm{~s}, 9 \mathrm{H}), 1.51-1.90(\mathrm{~m}$, $6 \mathrm{H}), 2.75-2.87(\mathrm{~m}, 1 \mathrm{H}), 3.28-3.39(\mathrm{~m}, 1 \mathrm{H}), 4.46-4.53(\mathrm{~m}$, 1H), 6.89 (dd, $J=7.7 \mathrm{~Hz}, 4.9 \mathrm{~Hz}, 1 \mathrm{H}), 7.09-7.24$ (m, 4H), 7.76 (br d, $J=6.7 \mathrm{~Hz}, 1 \mathrm{H}$ ), 8.34 (br d, $J=3.6 \mathrm{~Hz}$, 1H) $\mathrm{ppm} ;{ }^{13} \mathrm{C} \mathrm{NMR}\left(\mathrm{CDCl}_{3}, 50 \mathrm{MHz}\right): \delta=24.6,26.1$, 31.3, 34.2, 35.3, 56.2, 63.6, 115.5, 121.2 (q, $J=30.8 \mathrm{~Hz}$ ), $123.6 \quad(\mathrm{q}, \quad J=272.7 \mathrm{~Hz}), \quad 124.5, \quad 127.4,136.3 \quad(\mathrm{q}$, $J=5.2 \mathrm{~Hz}), 141.0,148.7,151.1,162.5$ ppm; HR-MS: $[\mathrm{M}+\mathrm{H}]^{+} \mathrm{m} / \mathrm{z}($ predicted $)=363.2043, \mathrm{~m} / \mathrm{z}$ (measured $)=$ 263.2036.

2-(4-Fluorophenyl)-1-[3-(trifluoromethyl)pyridin-2-yl]piperidine (4d, $\mathrm{C}_{17} \mathrm{H}_{16} \mathrm{~F}_{4} \mathrm{~N}_{2}$ )

Yield: $43 \%$ (68.9 mg); slightly yellow solid; m.p.: 70-72 ${ }^{\circ} \mathrm{C} ;{ }^{1} \mathrm{H}$ NMR $\left(\mathrm{CDCl}_{3}, 200 \mathrm{MHz}\right): \delta=1.46-1.94$ $(\mathrm{m}, 6 \mathrm{H}), 2.75(\mathrm{ddd}, J=11.2 \mathrm{~Hz}, 11.2 \mathrm{~Hz}, 3.1 \mathrm{~Hz}, 1 \mathrm{H})$, $3.28-3.38(\mathrm{~m}, 1 \mathrm{H}), 4.43(\mathrm{dd}, J=9.7 \mathrm{~Hz}, 3.3 \mathrm{~Hz}, 1 \mathrm{H})$, 6.73-6.83 (m, 2H), $6.95(\mathrm{dd}, J=7.8 \mathrm{~Hz}, 4.8 \mathrm{~Hz}, 1 \mathrm{H})$, $7.23-7.30$ (m, 2H), 7.78 (dd, $J=7.8 \mathrm{~Hz}, 1.6 \mathrm{~Hz}, 1 \mathrm{H}), 8.35$ $(\mathrm{dd}, J=4.7 \mathrm{~Hz}, 1.4 \mathrm{~Hz}, 1 \mathrm{H}) \mathrm{ppm} ;{ }^{13} \mathrm{C} \mathrm{NMR}\left(\mathrm{CDCl}_{3}\right.$, $50 \mathrm{MHz}): \delta=24.8,26.0,35.6,56.8,63.6,114.4(\mathrm{~d}$, $J=21.4 \mathrm{~Hz}), 119.2,121.9(\mathrm{q}, J=30.8 \mathrm{~Hz}), 123.4(\mathrm{q}$, $J=272.7 \mathrm{~Hz}), \quad 129.4 \quad(\mathrm{~d}, \quad J=7.7 \mathrm{~Hz}), \quad 136.2 \quad(\mathrm{q}$, $J=5.3 \mathrm{~Hz}), 140.0(\mathrm{~d}, J=3.2 \mathrm{~Hz}), 151.1,161.2 \quad(\mathrm{~d}$, $J=243.7 \mathrm{~Hz}$ ), 162.5 ppm; HR-MS: $[\mathrm{M}+\mathrm{H}]^{+} \mathrm{m} / z$ (predicted $)=325.1322, \mathrm{~m} / \mathrm{z}($ measured $)=325.1317$.

2-(4-Chlorophenyl)-1-[3-(trifluoromethyl)pyridin-2-yl]piperidine (4e, $\mathrm{C}_{17} \mathrm{H}_{16} \mathrm{ClF}_{3} \mathrm{~N}_{2}$ )

Yield: $34 \%$ (58.0 mg); colorless oil; ${ }^{1} \mathrm{H}$ NMR $\left(\mathrm{CDCl}_{3}\right.$, $400 \mathrm{MHz}): \delta=1.48-1.60(\mathrm{~m}, 1 \mathrm{H}), 1.72-1.91(\mathrm{~m}, 5 \mathrm{H})$, 2.73 (ddd, $J=11.6 \mathrm{~Hz}, 11.6 \mathrm{~Hz}, 2.5 \mathrm{~Hz}, 1 \mathrm{H}), 3.31-3.36$ (m, 1H), 4.42 (dd, $J=10.8 \mathrm{~Hz}, 2.5 \mathrm{~Hz}, 1 \mathrm{H}), 6.94$ (dd, $J=7.7 \mathrm{~Hz}, 4.9 \mathrm{~Hz}, 1 \mathrm{H}), 7.06$ (d, $J=8.3 \mathrm{~Hz}, 2 \mathrm{H}), 7.24$ $(\mathrm{d}, J=8.5 \mathrm{~Hz}, 2 \mathrm{H}), 7.78(\mathrm{dd}, J=7.8 \mathrm{~Hz}, 1.7 \mathrm{~Hz}, 1 \mathrm{H})$, $8.34(\mathrm{dd}, J=4.7 \mathrm{~Hz}, 1.5 \mathrm{~Hz}, 1 \mathrm{H}) \mathrm{ppm} ;{ }^{13} \mathrm{C} \mathrm{NMR}\left(\mathrm{CDCl}_{3}\right.$, 
$100 \mathrm{MHz}): \delta=24.8,26.0,35.6,56.9,63.7,119.2,121.8$ $(\mathrm{q}, J=30.9 \mathrm{~Hz}), 123.4(\mathrm{q}, J=272.7 \mathrm{~Hz}), 127.9,129.3$, 131.7, 136.3 (q, $J=5.2 \mathrm{~Hz}), 142.9,151.2,162.3 \mathrm{ppm}$; HR-MS: $[\mathrm{M}+\mathrm{H}]^{+} \mathrm{m} / \mathrm{z} \quad($ predicted $)=341.1027, \quad \mathrm{~m} / \mathrm{z}$ $($ measured $)=341.1035$.

\section{2-(4-Methoxyphenyl)-1-[3-(trifluoromethyl)pyridin-2-yl]-} piperidine (4f, $\mathrm{C}_{18} \mathrm{H}_{19} \mathrm{~F}_{3} \mathrm{~N}_{2} \mathrm{O}$ )

Yield: $16 \%$ (26.5 mg); slightly yellow solid; m.p.: $69-72{ }^{\circ} \mathrm{C}$; ${ }^{1} \mathrm{H}$ NMR $\left(\mathrm{CDCl}_{3}, 200 \mathrm{MHz}\right): \delta=1.46-1.91$ $(\mathrm{m}, 6 \mathrm{H}), 2.76(\mathrm{ddd}, J=11.3 \mathrm{~Hz}, 11.3 \mathrm{~Hz}, 3.1 \mathrm{~Hz}, 1 \mathrm{H})$, $3.26-3.36(\mathrm{~m}, 1 \mathrm{H}), 3.68(\mathrm{~s}, 3 \mathrm{H}), 4.40(\mathrm{dd}, J=9.1 \mathrm{~Hz}$, $3.8 \mathrm{~Hz}, 1 \mathrm{H}), 6.64(\mathrm{~d}, \quad J=8.6 \mathrm{~Hz}, 2 \mathrm{H}), 6.93 \quad(\mathrm{dd}$, $J=7.8 \mathrm{~Hz}, 4.8 \mathrm{~Hz}, 1 \mathrm{H}), 7.22$ (d, $J=8.6 \mathrm{~Hz}, 2 \mathrm{H}), 7.77$ $(\mathrm{dd}, J=7.8 \mathrm{~Hz}, 1.6 \mathrm{~Hz}, 1 \mathrm{H}), 8.36$ (br d, $J=3.8 \mathrm{~Hz}$, 1H) $\mathrm{ppm} ;{ }^{13} \mathrm{C} \mathrm{NMR}\left(\mathrm{CDCl}_{3}, 50 \mathrm{MHz}\right): \delta=24.9,26.1$, $35.5, \quad 55.0, \quad 56.7, \quad 63.6, \quad 113.0, \quad 119.0, \quad 121.8 \quad$ (q, $J=30.8 \mathrm{~Hz}), 123.5(\mathrm{q}, J=272.7 \mathrm{~Hz}), 129.1,136.2(\mathrm{qd}$, $\left.{ }^{3} J=5.2 \mathrm{~Hz}\right), 136.4,151.1,157.8,162.7$ ppm; HR-MS: $[\mathrm{M}+\mathrm{H}]^{+} \mathrm{m} / \mathrm{z}($ predicted $)=337.1522, \mathrm{~m} / \mathrm{z}$ (measured $)=$ 337.1515 .

2-(4-Trifluoromethylphenyl)-1-[3-(trifluoromethyl)pyridin2-yl]piperidine $\left(\mathbf{4 g}, \mathrm{C}_{18} \mathrm{H}_{16} \mathrm{~F}_{6} \mathrm{~N}_{2}\right)$

Yield: $40 \% \quad(74.9 \mathrm{mg})$; slightly yellow solid; m.p.: 60-62 ${ }^{\circ} \mathrm{C}$; ${ }^{1} \mathrm{H}$ NMR $\left(\mathrm{CDCl}_{3}, 400 \mathrm{MHz}\right): \delta=1.53-1.62$ $(\mathrm{m}, 1 \mathrm{H}), 1.73-1.93(\mathrm{~m}, 5 \mathrm{H}), 2.74(\mathrm{ddd}, J=11.6 \mathrm{~Hz}$, $11.6 \mathrm{~Hz}, 2.5 \mathrm{~Hz}, 1 \mathrm{H}), 3.35-3.40$ (m, 1H), 4.53 (dd, $J=10.9 \mathrm{~Hz}, 2.4 \mathrm{~Hz}, 1 \mathrm{H}), 6.95(\mathrm{dd}, J=7.7 \mathrm{~Hz}, 4.9 \mathrm{~Hz}$, $1 \mathrm{H}), 7.35$ (d, $J=8.3 \mathrm{~Hz}, 2 \mathrm{H}), 7.42(\mathrm{~d}, J=8.2 \mathrm{~Hz}, 2 \mathrm{H})$, $7.80(\mathrm{dd}, J=7.8 \mathrm{~Hz}, 1.7 \mathrm{~Hz}, 1 \mathrm{H}), 8.32(\mathrm{dd}, J=4.8 \mathrm{~Hz}$, $1.4 \mathrm{~Hz}, 1 \mathrm{H}) \mathrm{ppm} ;{ }^{13} \mathrm{C} \mathrm{NMR}\left(\mathrm{CDCl}_{3}, 100 \mathrm{MHz}\right): \delta=24.7$, 26.0, 35.6, 56.9, 64.0, 119.3, 121.7 (q, $J=30.9 \mathrm{~Hz})$, $123.4(\mathrm{q}, \quad J=272.8 \mathrm{~Hz}), \quad 124.2(\mathrm{q}, \quad J=271.8 \mathrm{~Hz})$, $124.8(\mathrm{q}, J=3.8 \mathrm{~Hz}), 128.1,128.4(\mathrm{q}, J=32.3 \mathrm{~Hz})$, 136.5 (q, $J=5.2 \mathrm{~Hz}$ ), 148.6, 151.1, 162.0 ppm; HR-MS: $[\mathrm{M}+\mathrm{H}]^{+} \mathrm{m} / \mathrm{z}($ predicted $)=375.1290, \mathrm{~m} / \mathrm{z}$ (measured $)=$ 375.1280 .

\section{2-(m-Tolyl)-1-[3-(trifluoromethyl)pyridin-2-yl]piperidine} $\left(4 \mathbf{j}, \mathrm{C}_{18} \mathrm{H}_{19} \mathrm{~F}_{3} \mathrm{~N}_{2}\right)$

Yield: $49 \%$ (78.8 mg) colorless solid; m.p.: $80-82{ }^{\circ} \mathrm{C} ;{ }^{1} \mathrm{H}$ NMR $\left(\mathrm{CDCl}_{3}, 200 \mathrm{MHz}\right): \delta=1.47-1.88(\mathrm{~m}, 6 \mathrm{H}), 2.19$ (s, $3 \mathrm{H}), 2.73$ (ddd, $J=11.3 \mathrm{~Hz}, 11.3 \mathrm{~Hz}, 2.9 \mathrm{~Hz}, 1 \mathrm{H})$, $3.27-3.38(\mathrm{~m}, 1 \mathrm{H}), 4.43(\mathrm{dd}, J=9.3 \mathrm{~Hz}, 3.3 \mathrm{~Hz}, 1 \mathrm{H})$, 6.79-7.16 (m, 5H), 7.75 (dd, $J=7.8 \mathrm{~Hz}, 1.6 \mathrm{~Hz}, 1 \mathrm{H}), 8.33$ $(\mathrm{dd}, J=4.8 \mathrm{~Hz}, 1.3 \mathrm{~Hz}, 1 \mathrm{H}) \mathrm{ppm} ;{ }^{13} \mathrm{C} \mathrm{NMR}\left(\mathrm{CDCl}_{3}\right.$, $50 \mathrm{MHz}): \delta=21.3,24.8,26.1,35.6,56.7,64.2,118.9$, $121.6(\mathrm{q}, J=30.9 \mathrm{~Hz}), 123.5(\mathrm{q}, J=272.7 \mathrm{~Hz}), 124.9$, $126.9,127.5,128.6,136.3(\mathrm{q}, J=5.2 \mathrm{~Hz}), 137.1,144.3$, 151.1, 162.6 ppm; HR-MS: $[\mathrm{M}+\mathrm{H}]^{+} \mathrm{m} / \mathrm{z}$ (predicted $)=$ $321.1573, \mathrm{~m} / \mathrm{z}$ (measured $)=321.1569$.
2-(3-Chlorophenyl)-1-[3-(trifluoromethyl)pyridin-2-yl]piperidine $\left(4 \mathbf{k}, \mathrm{C}_{17} \mathrm{H}_{16} \mathrm{ClF}_{3} \mathrm{~N}_{2}\right)$

Yield: $39 \%$ (66.6 mg); colorless solid; m.p.: $82-84{ }^{\circ} \mathrm{C} ;{ }^{1} \mathrm{H}$ NMR $\left(\mathrm{CDCl}_{3}, 200 \mathrm{MHz}\right): \delta=1.45-1.92(\mathrm{~m}, 6 \mathrm{H}), 2.72$ (ddd, $J=11.2 \mathrm{~Hz}, 11.2 \mathrm{~Hz}, 3.1 \mathrm{~Hz}, 1 \mathrm{H}), 3.29-3.39$ (m, 1H), 4.45 (dd, $J=10.1 \mathrm{~Hz}, 2.5 \mathrm{~Hz}, 1 \mathrm{H}), 6.92-7.06(\mathrm{~m}$, $3 \mathrm{H}), 7.15-7.26(\mathrm{~m}, 1 \mathrm{H}), 7.33$ (br s, 1H), 7.80 (dd, $J=7.8 \mathrm{~Hz}, 1.4 \mathrm{~Hz}, 1 \mathrm{H}), 8.35(\mathrm{dd}, J=4.8 \mathrm{~Hz}, 1.2 \mathrm{~Hz}$, 1H) $\mathrm{ppm} ;{ }^{13} \mathrm{C} \mathrm{NMR}\left(\mathrm{CDCl}_{3}, 100 \mathrm{MHz}\right): \delta=24.7,26.0$, $35.5,56.8,63.8,119.2,121.7$ (q, $J=30.9 \mathrm{~Hz}), 123.5$ (q, $J=272.6 \mathrm{~Hz}), 126.1,126.4,128.1,129.0,133.5,136.4(\mathrm{q}$, $J=5.1 \mathrm{~Hz}), 146.5,151.2,162.2$ ppm; HR-MS: $[\mathrm{M}+\mathrm{H}]^{+}$ $\mathrm{m} / \mathrm{z}($ predicted $)=341.1027, \mathrm{~m} / \mathrm{z}($ measured $)=341.1017$.

4-Methyl-2-phenyl-1-[3-(trifluoromethyl)pyridin-2-yl]piperidine $\left(8, \mathrm{C}_{18} \mathrm{H}_{19} \mathrm{~F}_{3} \mathrm{~N}_{2}\right)$

Yield: $28 \%$ (44.4 mg); colorless solid; m.p.: $106-108{ }^{\circ} \mathrm{C}$; ${ }^{1} \mathrm{H} \mathrm{NMR}\left(\mathrm{CDCl}_{3}, 400 \mathrm{MHz}\right): \delta=1.00(\mathrm{~d}, J=6.2 \mathrm{~Hz}, 3 \mathrm{H})$, 1.44-1.61 (m, 2H), 1.68-1.78 (m, 2H), 1.84-1.89 (m, 1H), 2.75 (ddd, $J=11.9 \mathrm{~Hz}, 11.9 \mathrm{~Hz}, 1.8 \mathrm{~Hz}, 1 \mathrm{H}$ ), 3.43 (ddd, $J=11.7 \mathrm{~Hz}, 11.7 \mathrm{~Hz}, 3.1 \mathrm{~Hz}, 1 \mathrm{H}), 4.42(\mathrm{dd}, J=11.5 \mathrm{~Hz}$, $1.9 \mathrm{~Hz}, 1 \mathrm{H}), 6.92(\mathrm{dd}, J=7.6 \mathrm{~Hz}, 4.9 \mathrm{~Hz}, 1 \mathrm{H}), 7.06-7.10$ (m, 1H), 7.08 (br dd, $J=7.5 \mathrm{~Hz}, 7.5 \mathrm{~Hz}, 2 \mathrm{H}$ ), 7.30 (br d, $J=7.5 \mathrm{~Hz}, 2 \mathrm{H}), 7.76(\mathrm{dd}, J=7.8 \mathrm{~Hz}, 1.6 \mathrm{~Hz}, 1 \mathrm{H}), 8.33$ $(\mathrm{dd}, J=4.7 \mathrm{~Hz}, 1.4 \mathrm{~Hz}, 1 \mathrm{H}) \mathrm{ppm} ;{ }^{13} \mathrm{C} \mathrm{NMR}\left(\mathrm{CDCl}_{3}\right.$, $100 \mathrm{MHz}): \delta=22.0,31.7,34.5,44.7,57.0,64.4,119.3$, $122.3(\mathrm{q}, J=30.6 \mathrm{~Hz}), 123.4(\mathrm{q}, J=272.9 \mathrm{~Hz}), 126.2$, 127.7, 127.9, $136.2 \quad(\mathrm{q}, J=5.1 \mathrm{~Hz}), \quad 144.4, \quad 151.1$, 162.7 ppm; HR-MS: $[\mathrm{M}+\mathrm{H}]^{+} \mathrm{m} / \mathrm{z} \quad($ predicted $)=$ $321.1573, \mathrm{~m} / \mathrm{z}($ measured $)=321.1565$.

Ethyl 2-phenyl-1-[3-(trifluoromethyl)pyridin-2-yl]piperidine-4-carboxylate $\left(9, \mathrm{C}_{20} \mathrm{H}_{21} \mathrm{~F}_{3} \mathrm{~N}_{2} \mathrm{O}_{2}\right)$

Yield: $25 \%$ (47.6 mg); slightly yellow solid; m.p.: ${ }^{74-76}{ }^{\circ} \mathrm{C} ;{ }^{1} \mathrm{H}$ NMR $\left(\mathrm{CDCl}_{3}, 200 \mathrm{MHz}\right): \delta=1.25(\mathrm{t}$, $J=7.1 \mathrm{~Hz}, 3 \mathrm{H}), 1.86-2.21(\mathrm{~m}, 4 \mathrm{H}), 2.55-2.84(\mathrm{~m}, 2 \mathrm{H})$, 3.43 (ddd, $J=11.7 \mathrm{~Hz}, 11.7 \mathrm{~Hz}, 3.4 \mathrm{~Hz}, 1 \mathrm{H}), 4.14$ (q, $J=7.1 \mathrm{~Hz}, 2 \mathrm{H}), 4.46(\mathrm{dd}, J=11.3 \mathrm{~Hz}, 2.4 \mathrm{~Hz}, 1 \mathrm{H})$, 6.92-7.14 (m, 3H), 7.29-7.34 (m, 2H), 7.78 (dd, $J=7.8 \mathrm{~Hz}, 1.5 \mathrm{~Hz}, 1 \mathrm{H}), 8.34(\mathrm{dd}, J=4.5 \mathrm{~Hz}, 1.2 \mathrm{~Hz}$, 1H) ppm; ${ }^{13} \mathrm{C} \mathrm{NMR}\left(\mathrm{CDCl}_{3}, 100 \mathrm{MHz}\right): \delta=14.2,28.5$, 37.9, 42.2, 56.0, 63.8, 119.7, 122.4 (q, $J=31.0 \mathrm{~Hz}), 123.4$ $(\mathrm{q}, \quad J=272.8 \mathrm{~Hz}), \quad 126.6, \quad 127.8, \quad 128.0,136.3 \quad(\mathrm{q}$, $J=5.1 \mathrm{~Hz}), 141.2,151.1,162.1$ ppm; HR-MS: $[\mathrm{M}+\mathrm{H}]^{+}$ $\mathrm{m} / \mathrm{z}($ predicted $)=379.1628, \mathrm{~m} / \mathrm{z}($ measured $)=379.1629$.

4-Benzyl-2-phenyl-1-[3-(trifluoromethyl)pyridin-2-yl]piperidine (10, $\mathrm{C}_{24} \mathrm{H}_{23} \mathrm{~F}_{3} \mathrm{~N}_{2}$ )

Yield: $34 \%$ (67.8 mg); slightly yellow gum; ${ }^{1} \mathrm{H}$ NMR $\left(\mathrm{CDCl}_{3}, 200 \mathrm{MHz}\right): \delta=1.46-1.93(\mathrm{~m}, 5 \mathrm{H}), 2.59-2.76(\mathrm{~m}$, 2H), 3.35 (ddd, $J=11.7 \mathrm{~Hz}, 11.7 \mathrm{~Hz}, 3.2 \mathrm{~Hz}, 1 \mathrm{H}), 4.39$ (bd, $J=9.8 \mathrm{~Hz}, 1 \mathrm{H}), 6.87-7.31(\mathrm{~m}, 11 \mathrm{H}), 7.75(\mathrm{dd}$, $J=7.8 \mathrm{~Hz}, 1.6 \mathrm{~Hz}, 1 \mathrm{H}), 8.31(\mathrm{dd}, J=4.7 \mathrm{~Hz}, 1.3 \mathrm{~Hz}$, 
1H) $\mathrm{ppm} ;{ }^{13} \mathrm{C}$ NMR $\left(\mathrm{CDCl}_{3}, 100 \mathrm{MHz}\right): \delta=32.4,38.8$, 42.5, 43.4, 56.8, 64.3, 119.4, 122.3 (q, $J=30.8 \mathrm{~Hz}), 123.5$ $(\mathrm{q}, J=272.7 \mathrm{~Hz}), 125.9,126.3,127.7,128.0,128.3$, $129.2, \quad 136.2 \quad(\mathrm{q}, \quad J=5.1 \mathrm{~Hz}), \quad 140.5, \quad 144.2, \quad 151.1$, $162.5 \mathrm{ppm}$; HR-MS: $[\mathrm{M}+\mathrm{H}]^{+} \mathrm{m} / \mathrm{z}$ (predicted) $=397$. $1886, \mathrm{~m} / \mathrm{z}$ (measured) $=397.1888$.

\section{2-Phenyl-1-[3-(trifluoromethyl)pyridin-2-yl]pyrrolidine}

$\left(11, \mathrm{C}_{16} \mathrm{H}_{15} \mathrm{~F}_{3} \mathrm{~N}_{2}\right)$

Yield: $49 \%$ (72.2 mg); slightly yellow solid; m.p.: $81-84{ }^{\circ} \mathrm{C} ;{ }^{1} \mathrm{H}$ NMR $\left(\mathrm{CDCl}_{3}, 400 \mathrm{MHz}\right): \delta=1.82-2.07$ (m, 3H), 2.37-2.42 (m, 1H), 3.57-3.61 (m, 1H), 3.92-3.98 $(\mathrm{m}, 1 \mathrm{H}), 5.54(\mathrm{dd}, J=7.8 \mathrm{~Hz}, 7.8 \mathrm{~Hz}, 1 \mathrm{H}), 6.61(\mathrm{dd}$, $J=7.7 \mathrm{~Hz}, 4.7 \mathrm{~Hz}, 1 \mathrm{H}), 7.13-7.16(\mathrm{~m}, 1 \mathrm{H}), 7.24(\mathrm{t}$, $J=7.5 \mathrm{~Hz}, 2 \mathrm{H}), 7.30(\mathrm{~d}, J=7.9 \mathrm{~Hz}, 2 \mathrm{H}), 7.74(\mathrm{dd}$, $J=7.7 \mathrm{~Hz}, \quad 1.2 \mathrm{~Hz}, \quad 1 \mathrm{H}), \quad 8.32$ (br $\mathrm{d}, \quad J=4.4 \mathrm{~Hz}$, 1H) $\mathrm{ppm} ;{ }^{13} \mathrm{C}$ NMR $\left(\mathrm{CDCl}_{3}, 100 \mathrm{MHz}\right): \delta=26.0,35.9$, $52.5\left(\mathrm{q},{ }^{5} J=5.2 \mathrm{~Hz}\right), 63.1,111.1(\mathrm{q}, J=30.9 \mathrm{~Hz}), 112.6$, $123.2(\mathrm{q}, J=271.7 \mathrm{~Hz}), 126.1,126.3,128.2,136.9$ (q, $J=5.7 \mathrm{~Hz}), 144.9,150.4,155.5$ ppm; HR-MS: $[\mathrm{M}+\mathrm{H}]^{+}$ $\mathrm{m} / \mathrm{z}($ predicted $)=293.1260, \mathrm{~m} / \mathrm{z}($ measured $)=293.1249$.

\section{2-Phenyl-1-(3,4,5,6-tetrahydropyridin-2-yl)piperidine}

$\left(17, \mathrm{C}_{16} \mathrm{H}_{22} \mathrm{~N}_{2}\right)$

$\mathrm{PtO}_{2}$.aq (16.3 mg, $\left.0.072 \mathrm{mmol}, 5 \mathrm{~mol} \%\right)$ was placed in a three-necked $25-\mathrm{cm}^{3}$ flask equipped with a magnetic stirrer. The flask was evacuated and flushed with nitrogen three times, and then $7.2 \mathrm{~cm}^{3} i$-PrOH was added with a syringe through a septum. After stirring the mixture at room temperature (RT) for some minutes, a solution of $441 \mathrm{mg} \mathbf{4 a}(1.44 \mathrm{mmol}$, 1 equiv.) in $7.2 \mathrm{~cm}^{3} i$-PrOH and $1.4 \mathrm{~cm}^{3} 2 \mathrm{~N} \mathrm{HCl}$ was added to the catalyst with a syringe. The flask was flushed with hydrogen two times, and a hydrogen balloon was attached. The reaction mixture was then stirred at RT for $14 \mathrm{~h}$ and filtered through a pad of Celite $^{\circledR}$, and the solvent was evaporated. The residue was taken up in $1 \mathrm{~N} \mathrm{NaOH}$ solution and subsequently extracted with $\mathrm{CH}_{2} \mathrm{Cl}_{2}$ three times. The combined organic layers were dried over $\mathrm{Na}_{2} \mathrm{SO}_{4}$, filtered, and evaporated to dryness. The crude product was then diluted in $5 \mathrm{~cm}^{3} \mathrm{CH}_{2} \mathrm{Cl}_{2}$ and stirred in the presence of $1.6 \mathrm{~g}$ silica gel in a closed vial at $50{ }^{\circ} \mathrm{C}$ for $2.5 \mathrm{~h}$. Afterwards, the crude product was directly rotated onto the silica gel and purified by silica gel flash column chromatography. Yield: $72 \%(252 \mathrm{mg})$; colorless oil; ${ }^{1} \mathrm{H}$ NMR $\left(\mathrm{CDCl}_{3}, 200 \mathrm{MHz}\right): \delta=1.36-2.41(\mathrm{~m}$, $12 \mathrm{H}), 2.75-2.87(\mathrm{~m}, 1 \mathrm{H}), 3.43-3.66(\mathrm{~m}, 2 \mathrm{H}), 4.12(\mathrm{br} \mathrm{d}$, $J=13.3 \mathrm{~Hz}, 1 \mathrm{H}), 5.36$ (br s, $1 \mathrm{H}), 7.16-7.36(\mathrm{~m}, 5 \mathrm{H}) \mathrm{ppm}$; ${ }^{13} \mathrm{C} \mathrm{NMR}\left(\mathrm{CDCl}_{3}, 200 \mathrm{MHz}\right): \delta=19.7,21.0,22.6,24.8$, $25.5,29.0,40.0,47.2,52.8,126.1,126.7,128.5,141.6$, 155.7 ppm; HR-MS: $[\mathrm{M}+\mathrm{H}]^{+} \mathrm{m} / z$ (predicted) $=243.1856$, $\mathrm{m} / \mathrm{z}$ (measured $)=243.1846$.

\section{2-Phenylpiperidine (18)}

A three-necked $25-\mathrm{cm}^{3}$ flask, equipped with a magnetic

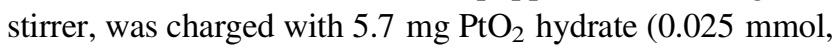

$5 \mathrm{~mol} \%$ ), evacuated, and flushed with nitrogen three times. Then, $2.5 \mathrm{~cm}^{3} i$-PrOH was added with a syringe through a septum, and the mixture was stirred at RT. After some minutes, a solution of $153 \mathrm{mg} \mathbf{4 a}(0.5 \mathrm{mmol}, 1$ equiv.) in $2.5 \mathrm{~cm}^{3} i$-PrOH and $0.5 \mathrm{~cm}^{3} 2 \mathrm{~N} \mathrm{HCl}$ was added to the catalyst with a syringe. The flask was flushed with hydrogen two times, and a hydrogen balloon was attached. The reaction mixture was then stirred at RT for $14 \mathrm{~h}$ and filtered through a pad of Celite ${ }^{\circledR}$, and the solvent was evaporated. The residue was taken up in $1 \mathrm{~N} \mathrm{NaOH}$ solution and subsequently extracted with $\mathrm{CH}_{2} \mathrm{Cl}_{2}$ three times. The combined organic layers were dried over $\mathrm{Na}_{2} \mathrm{SO}_{4}$, filtered, and evaporated to dryness. The crude product $\mathbf{1 6}$ was then diluted in $2.5 \mathrm{~cm}^{3} \mathrm{CH}_{2} \mathrm{Cl}_{2}$ and stirred in the presence of $700 \mathrm{mg}$ silica gel in a closed vial at $50{ }^{\circ} \mathrm{C}$ for $2.5 \mathrm{~h}$. The crude intermediate $\mathbf{1 7}$ was eluted from the silica gel with a mixture of EtOAc and $\mathrm{Et}_{3} \mathrm{~N}$ (15:1, then 1:1), evaporated to dryness, and then treated with $2.5 \mathrm{~cm}^{3} \mathrm{NH}_{2} \mathrm{NH}_{2} / \mathrm{AcOH}$ (2.5 M/0.7 M in EtOH) at $120{ }^{\circ} \mathrm{C}$ for $2 \mathrm{~h}$ in a closed microwave vial under nitrogen atmosphere. Again the solvent was evaporated, and the residue was brought in $2 \mathrm{~N} \mathrm{NaOH}$ solution and subsequently extracted with $\mathrm{Et}_{2} \mathrm{O}$ three times. Evaporation to dryness yielded the crude product. This was further purified by silica gel flash column chromatography, affording $37.9 \mathrm{mg}(47 \%) \mathbf{1 8}$ as colorless gum. NMR spectra were found to be in accordance with the ones described in reference [36].

\section{Computational details}

All calculations were performed using the Gaussian09 software package on the Phoenix Linux Cluster of the Vienna University of Technology [42]. The geometry and energy of the model compounds were optimized at the PBE1PBE level [43-45] with the 6-31G** basis set employed for all atoms [46-52]. All geometries were optimized without symmetry constraints. Frequency calculations were performed to confirm the nature of the stationary points, yielding no imaginary frequencies.

Acknowledgments We acknowledge the Austrian Science Foundation (FWF, project P21202-N17) for financial support of this work.

Open Access This article is distributed under the terms of the Creative Commons Attribution License which permits any use, distribution, and reproduction in any medium, provided the original author(s) and the source are credited.

\section{References}

1. Bergmann RG (2007) Nature 446:391

2. Sames D, Godula K (2006) Science $312: 67$

3. Labinger JA, Bercaw JE (2002) Nature 417:507 
4. Shilov AE, Shulpin GB (1997) Chem Rev 97:2879

5. Yu JQ, Shi Z (eds) (2010) C-H activation. Springer, Heidelberg

6. Dyker G (ed) (2005) Handbook of C-H transformations. WileyVCH, Weinheim

7. Schnürch M, Dastbaravardeh N, Ghobrial M, Mrozek B, Mihovilovic MD (2011) Curr Org Chem 15:2694

8. Ackermann L, Vicente R, Kapdi AR (2009) Angew Chem Int Ed 48:9792

9. Ackermann L, Diers E, Manvar A (2012) Org Lett 14:1154

10. Wencel-Delord J, Nimphius C, Patureau FW, Glorius F (2012) Angew Chem Int Ed 51:2247

11. Flegeau EF, Bruneau C, Dixneuf PH, Jutand A (2011) J Am Chem Soc 133:10161

12. Shiota H, Ano Y, Aihara Y, Fukumoto Y, Chatani N (2011) J Am Chem Soc 133:14952

13. Tauchert $\mathrm{ME}$, Incarvito $\mathrm{CD}$, Rheingold $\mathrm{AL}$, Bergman RG, Ellman JA (2012) J Am Chem Soc 134:1482

14. Koley M, Dastbaravardeh N, Schnürch M, Mihovilovic MD (2012) Chem Cat Chem 4:1345

15. Kakiuchi F, Chatani N (2003) Adv Synth Catal 345:1077

16. Fairlamb IJS (2007) Annu Rep Prog Chem Sect B Org Chem 103:68

17. McGlacken GP, Bateman LM (2009) Chem Soc Rev 38:2447

18. Rousseaux S, Gorelsky SI, Chung BKW, Fagnou K (2010) J Am Chem Soc 132:10692

19. Pan S, Endo K, Shibata T (2011) Org Lett 13:4692

20. Sundararaju B, Achard M, Sharma GVM, Bruneau C (2011) J Am Chem Soc 133:10340

21. Jazzar R, Hitce J, Renaudat A, Sofack-Kreutzer J, Baudoin O (2010) Chem Eur J 16:2654

22. Shabashov D, Daugulis O (2005) Org Lett 7:3657

23. Murahashi SI, Komiya N, Terai H (2005) Angew Chem Int Ed 44:6931

24. Tsuchikama K, Kasagawa M, Endo K, Shibata T (2009) Org Lett $11: 1821$

25. Chaumontet M, Piccardi R, Baudoin O (2009) Angew Chem Int Ed 48:179

26. Bellina F, Rossi R (2010) Chem Rev 110:1082

27. Sundararaju B, Tang Z, Achard M, Sharma GVM, Toupet L, Bruneau C (2010) Adv Synth Catal 352:3141

28. Ghobrial M, Harhammer K, Mihovilovic MD, Schnürch M (2010) Chem Commun 46:8836

29. Baudoin O (2011) Chem Soc Rev 40:4902

30. Wasa M, Engle KM, Lin DW, Yoo EJ, Yu JQ (2011) J Am Chem Soc 133:19598

31. Ghobrial M, Schnürch M, Mihovilovic MD (2011) J Org Chem $76: 8781$

32. Guo Z, Orth P, Zhu Z, Mazzola RD, Chan TY, Vaccaro HA, Mc Kittrick B, Kozlowski JA, Lavey BJ, Zhou G, Paliwal S, Wong S-C, Shih N-Y, Ting PC, Rosner KE, Shipps GW Jr, Siddiqui MA, Belanger DB, Dai C, Li D, Girijavallabhan VM, Popovici-
Muller J, Yu W, Zhao L (2005) Preparation of tartaric acid functional compounds for the treatment of inflammatory disorders. Chem Abstr 144:69727 (PCT Int Appl WO2005121130 A2, 2 Jun 2004)

33. Scott JD, Weinstein J, Miller MW, Stamford AW, Gilbert EJ, Xia Y, Greenlee WJ, Li W (2007) Diaryl piperidines as CB1 modulators and their preparation, pharmaceutical compositions and use in the treatment of diseases. Chem Abstr 147:211739 (PCT Int Appl WO2007084319 A2, 26 Jul 2007)

34. Campos KR (2007) Chem Soc Rev 36:1069

35. Pastine SJ, Gribkov DV, Sames D (2006) J Am Chem Soc 128:14220

36. Prokopcova H, Bergman SD, Aelvoet K, Smout V, Herrebout W, Van der Veken B, Meerpoel L, Maes BUW (2010) Chem Eur J $16: 13063$

37. Dastbaravardeh N, Schnürch M, Mihovilovic MD (2012) Org Lett 14:1930

38. Dastbaravardeh N, Kirchner K, Schnürch M, Mihovilovic MD (2013) J Org Chem 78:658

39. Dastbaravardeh N, Schnürch M, Mihovilovic MD (2012) Org Lett 14:3792

40. Schnürch M, Holzweber M, Mihovilovic MD, Stanetty P (2007) Green Chem 9:139

41. Seppelt K (1977) Angew Chem Int Ed 16:322

42. Frisch MJ, Trucks GW, Schlegel HB, Scuseria GE, Robb MA, Cheeseman Jr, Scalmani G, Barone V, Mennucci B, Petersson GA, Nakatsuji H, Caricato M, Li X, Hratchian HP, Izmaylov AF, Bloino J, Zheng G, Sonnenberg JL, Hada M, Ehara M, Toyota K, Fukuda R, Hasegawa J, Ishida M, Nakajima T, Honda Y, Kitao O, Nakai H, Vreven T, Montgomery JA Jr, Peralta JE, Ogliaro F, Bearpark M, Heyd JJ, Brothers E, Kudin KN, Staroverov VN, Kobayashi R, Normand J, Raghavachari K, Rendell A, Burant JC, Iyengar SS, Tomasi J, Cossi M, Rega N, Millam JM, Klene M, Knox JE, Cross JB, Bakken V, Adamo C, Jaramillo J, Gomperts R, Stratmann RE, Yazyev O, Austin AJ, Cammi R, Pomelli C, Ochterski JW, Martin RL, Morokuma K, Zakrzewski VG, Voth GA, Salvador P, Dannenberg JJ, Dapprich S, Daniels AD, Farkas Ö, Foresman JB, Ortiz JV, Cioslowski J, Fox DJ (2009) Gaussian 09, revision A.02. Gaussian Inc., Wallingford

43. Becke AD (1993) J Chem Phys 98:5648

44. Miehlich B, Savin A, Stoll H, Preuss H (1989) Chem Phys Lett 157:200

45. Lee C, Yang W, Parr G (1988) Phys Rev B 37:785

46. McLean AD, Chandler GS (1980) J Chem Phys 72:5639

47. Krishnan R, Binkley JS, Seeger R, Pople JA (1980) J Chem Phys 72:650

48. Wachters AJH (1970) Chem Phys 52:1033

49. Hay PJ (1977) J Chem Phys 66:4377

50. Raghavachari K, Trucks GW (1989) J Chem Phys 91:1062

51. Binning RC, Curtiss LA (1995) J Comput Chem 103:6104

52. McGrath MP, Radom L (1991) J Chem Phys 94:511 